Arkivoc

Free to Authors and Readers
A Platinum Open Access Journal for Organic Chemistry
Review

DOAJ Seal

Arkivoc 2021, part iii, 85-114

\title{
Fluorinated alcohols: powerful promoters for ring-opening reactions of epoxides with carbon nucleophiles
}

\author{
Taylor L. Dover and Frank E. McDonald* \\ Department of Chemistry, Emory University, 1515 Dickey Drive NE, Atlanta, GA 30322, USA \\ Email: frank.mcdonald@emory.edu
}

In honor of the 70th birthday of our colleague and mentor, Professor Lanny S. Liebeskind

Received 12-14-2020

Accepted 01-09-2021

Published on line $\quad 02-02-2021$

\begin{abstract}
Ring-opening reactions of epoxides with carbon nucleophiles are valuable transformations for constructing functionalized carbon-carbon bonds. Epoxide ring-opening methods typically require Lewis acidic additives and/or strong nucleophiles to overcome the activation barrier for these reactions. Fluorinated alcohol solvents present a desirable alternative, enhancing the efficacy of these reactions with weak and neutral carbon nucleophiles by promoting electrophilic activation of the epoxide. We present here a thorough review of the literature regarding epoxide ring-opening reactions with carbon nucleophiles in fluorinated alcohol solvents, concluding with a few recent examples with aziridines.
\end{abstract}

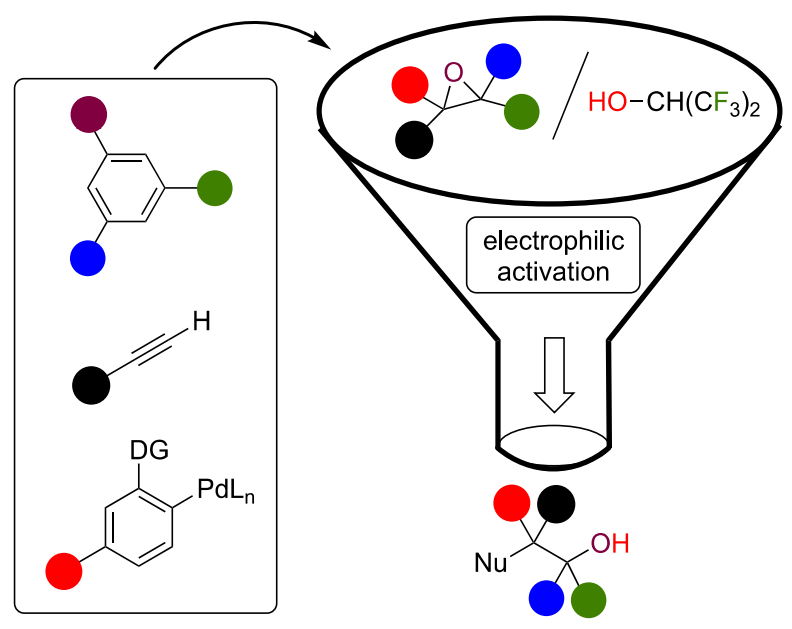

Keywords: Carbon nucleophiles, epoxides, fluorinated alcohols, ring-opening 


\section{Table of Contents}

1. Introduction

1.1 General

1.2 Properties of fluorinated alcohol solvents

2. Ring-opening Reactions with Neutral Carbon Nucleophiles, with Fluorinated Alcohol Solvents as Substitutes for Lewis acid Promoters or Catalysts

2.1 Intermolecular carbon-carbon bond-forming reactions

2.2 Intramolecular carbon-carbon bond-forming reactions

3. Ring-opening Reactions with Organopalladium Intermediates arising from Directed C-H Functionalization

3.1 Scope of reactions and conditions

3.2 Mechanistic proposals

4. Ring-opening Reactions with Terminal Alkyne Nucleophiles

5. Ring-opening Reactions of Aziridines with Carbon Nucleophiles in Fluorinated Solvents

6. Conclusions

Acknowledgements

References

Authors' Biographies

\section{Introduction}

\subsection{General}

Nucleophilic additions to epoxides are a common theme in chemical reactivity, ranging from preparations of poly(ethylene glycol) from ethylene oxide, ${ }^{1}$ to DNA alkylations of carcinogenic epoxide metabolites of polycyclic aromatic hydrocarbons. ${ }^{2}$ Despite the ring strain of the three-membered ring, epoxides are generally stable to long-term storage, due to the thermodynamic strength of the carbon-carbon and carbon-oxygen bonds. Therefore, many reactions of carbon nucleophiles with epoxides require either Lewis acidic reagents or catalysts to activate the latent electrophilicity of the epoxide, and/or highly nucleophilic main group organometallics, such as organolithium or organomagnesium compounds, which are also strongly basic.

Our interest in this topic arises from previous work from our laboratory involving epoxide electrophiles with carbon nucleophiles. These transformations have used strong Lewis acids, such as trimethylsilyl triflate (TMSOTf) for the intramolecular tricyclization of diepoxyenolsilane $\mathbf{1}$ to tricyclic ketone $\mathbf{2}^{3}$ and boron trifluoride-tetrahydrofuran ( $\mathrm{BF}_{3}-\mathrm{THF}$ ) for the intermolecular addition of alkyne $\mathbf{3}$ with epoxide $\mathbf{4}$ to produce alkynyl alcohol 5 (Scheme 1). ${ }^{4}$ Both examples required careful control of reaction time and temperature to attain the optimized yields.

In the past dozen years, other laboratories have reported several classes of ring-opening reactions of epoxides with carbon nucleophiles, using fluorinated alcohol solvents to promote these reactions under milder conditions or with greater efficiency than previously reported, including some transformations similar to those depicted in Scheme 1. 
TMSOTf, DTBMP

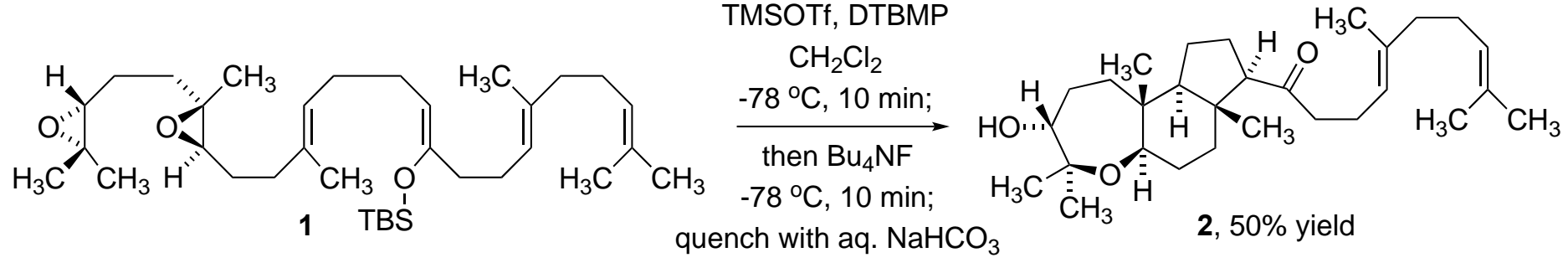

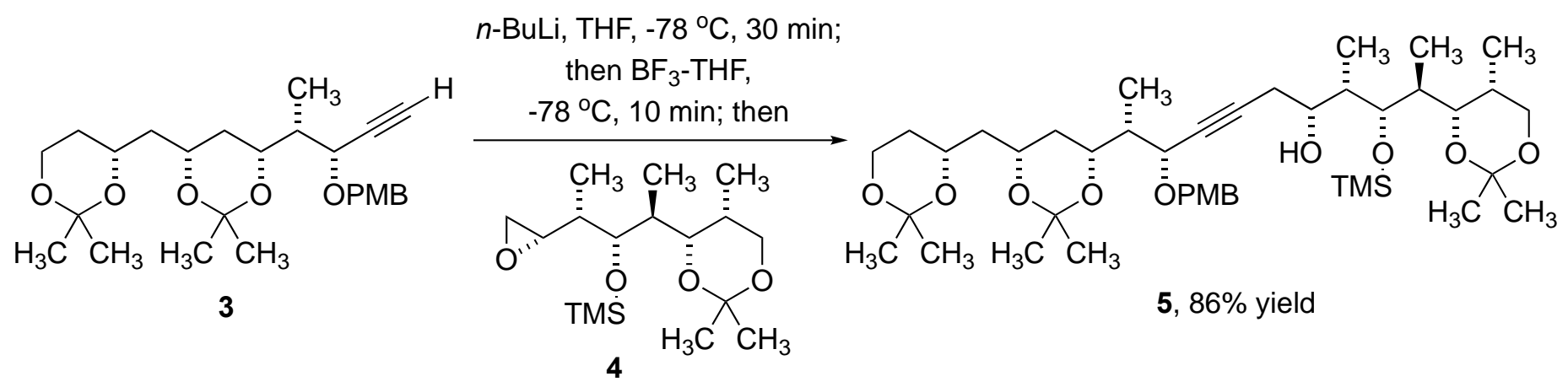

$-78^{\circ} \mathrm{C}, 2 \mathrm{~h}$; quench with $\mathrm{pH} 7$ buffer

Scheme 1. Representative examples of epoxide electrophiles reacting with carbon nucleophiles, without fluorinated alcohol solvents. DTBMP = 2,6-di-tert-butyl-4-methylpyridine; PMB = para-methoxybenzyl; TMS = trimethylsilyl.

The substantive 2004 review of Bégué et al. described fluorinated alcohol solvents activating ring-opening reactions of epoxides with several classes of heteroatom nucleophiles, including amines, thiols, and carboxylic acids. ${ }^{5}$ Subsequent reviews have presented the broader scope and relevance of fluorinated alcohol solvents in modern synthetic applications. ${ }^{6-12}$ This review focuses on ring-opening reactions of epoxides with carbon nucleophiles promoted by the fluorinated alcohol solvents 1,1,1,3,3,3-hexafluoro-2-propanol (HFIP) and 2,2,2trifluoroethanol (TFE, Figure 1). Our review concludes with a few examples of ring-opening reactions of aziridines with carbon nucleophiles in fluorinated alcohol solvents.<smiles>OC(C(F)(F)F)(C(F)(F)F)C(F)(F)F</smiles>

1,1,1,3,3,3-hexafluoro-2-propanol (HFIP)<smiles>OCC(F)(F)F</smiles>

2,2,2-trifluoroethanol (TFE)

Figure 1. Structures of fluorinated alcohol solvents.

To maintain focus, we have not extended this review beyond the heterocyclic epoxide and aziridine electrophiles, even though the analogous ring-opening reactions of aryl-substituted cyclopropanes with electron-rich aromatic nucleophiles in HFIP may be mechanistically related. ${ }^{13}$ Nonafluoro-tert-butyl alcohol (NFTB) promotes epoxide ring-opening with oxygen nucleophiles, including regioselective cascade cyclizations of polyepoxides terminated by alcohols, ${ }^{14}$ but we have not yet uncovered examples of NFTB with carbon nucleophiles adding to epoxides. 


\subsection{Properties of fluorinated alcohol solvents}

The fluoroalkyl groups of these alcohols confer several synthetically useful benefits to these solvents. Among these are (1) increased acidity relative to their non-fluorinated analogs; (2) comparatively low boiling points; (3) strong hydrogen bond donating abilities; and (4) markedly low solvent nucleophilicities (Table 1). ${ }^{11,16-21}$

Table 1. Selected properties of HFIP and TFE, compared with ethanol and water

\begin{tabular}{clcccc}
\hline entry & \multicolumn{1}{c}{ property } & HFIP & TFE & $\mathrm{CH}_{3} \mathrm{CH}_{2} \mathrm{OH}$ & $\mathrm{H}_{2} \mathrm{O}$ \\
\hline 1 & $\mathrm{p} K_{\mathrm{a}}\left(25^{\circ} \mathrm{C}, \text { water }\right)^{11,15}$ & 9.3 & 12.4 & 15.9 & 14.0 \\
2 & b. p. $\left({ }^{\circ} \mathrm{C}\right)^{16-18}$ & 58 & 74.3 & 78.3 & 100 \\
3 & Hydrogen Bond Donor $\left(\alpha_{1}\right)^{19}$ & 1.86 & 1.36 & 0.75 & 1.54 \\
4 & Hydrogen Bond Acceptor $\left(\beta_{1}\right)^{19}$ & 0.16 & 0.23 & 0.62 & 0.37 \\
5 & Solvent lonizing Power $(Y, 2 \text {-adamantyl tosylate })^{20}$ & $3.61^{\mathrm{a}}$ & $1.83^{\mathrm{b}}$ & -1.75 & $\mathrm{n} . \mathrm{r}$. \\
6 & Solvent lonizing Power $(Y, \text { tert-butyl chloride })^{20}$ & $2.46^{\mathrm{a}}$ & $1.15^{\mathrm{b}}$ & -2.03 & 3.49 \\
7 & Nucleophilicity $(N)^{21}$ & $-5.17^{\mathrm{a}}$ & $-3.25^{\mathrm{b}}$ & 0.55 & -1.47 \\
\hline
\end{tabular}

${ }^{\text {a }}$ For $97 \%(w / w)$ HFIP-H 2 O. ${ }^{b}$ For $97 \%(w / w)$ TFE- $\mathrm{H}_{2} \mathrm{O}$.

The electron-withdrawing fluoroalkyl groups are responsible for the low nucleophilicity and Brønsted acidity of fluorinated alcohol solvents. To illustrate, fluorinated alcohols exhibit enhanced acidity ( $\mathrm{p} K_{\mathrm{a}}$, Table 1 , entry 1 ) and strong hydrogen bond donating ability (entry 3), especially with ethereal oxygens. ${ }^{22,23}$ This results in an aggregation-induced decrease in the $\sigma^{*}$ OH orbital energy (Figure 2). For HFIP in the solid state, this complexation takes a helical form. ${ }^{23}$ In addition, HFIP is a strongly ionizing solvent, and is more than five orders of magnitude less nucleophilic than ethanol (entries 5-7). ${ }^{20,21,24,25}$ Fluorinated alcohol solvents are more expensive than the non-fluorinated congeners. However, bulk prices are currently as low as \$100 USD per kilogram, with TFE less expensive than HFIP. The low boiling points are desirable for recovering and recycling fluorinated alcohol solvents but present an upper limit on reaction temperature under refluxing conditions. ${ }^{26,27}$

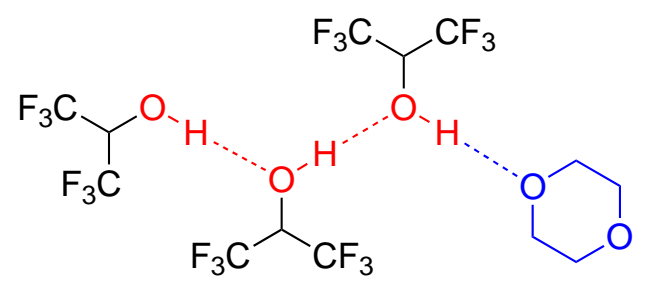

Figure 2. Aggregation of HFIP, depicting hydrogen bond donation with 1,4-dioxane.

Fluorinated alcohol solvents are about one order of magnitude more toxic than ethanol or 2-propanol, with $L_{50}$ values ranging from $300-600 \mathrm{mg} / \mathrm{kg}$ in mice (Table 2). ${ }^{28,29}$ The toxicity of TFE arises from metabolic oxidation pathways. ${ }^{30}$ Most biological studies focus on the in vivo production of TFE and HFIP as metabolites from fluorinated anesthetics and other fluoroorganic drugs. ${ }^{31}$ 
Table 2. Toxicity of HFIP and TFE

\begin{tabular}{cccc}
\hline & & \multicolumn{2}{c}{ LD $_{50}$ (mouse) } \\
\cline { 3 - 4 } entry & route & HFIP $^{28}$ & TFE $^{29}$ \\
\hline 1 & oral & $600 \mathrm{mg} / \mathrm{kg}$ & $366 \pm 106 \mathrm{mg} / \mathrm{kg}$ \\
2 & intraperitoneal & $300 \mathrm{mg} / \mathrm{kg}$ & $350 \pm 23 \mathrm{mg} / \mathrm{kg}$ \\
\hline
\end{tabular}

\section{Ring-opening Reactions with Neutral Carbon Nucleophiles, with Fluorinated Alcohol Solvents as Substitutes for Lewis Acid Promoters or Catalysts}

\subsection{Intermolecular carbon-carbon bond-forming reactions}

The alkylation of indoles with epoxides has typically required Lewis acid catalysis to activate epoxide C-O bond cleavage. In 2008, Westermaier and Mayr reported that indoles 6a - 6d reacted with equimolar $(R)$-styrene oxide (7) in TFE solvent, without additional Lewis acid, to provide the alkylated products $8 \mathbf{a}-\mathbf{8 d}($ Table 3$) .{ }^{32}$ The alkylations proceeded with regioselective addition at the benzylic carbon, and with complete stereospecificity, corresponding to inversion of configuration at the chiral carbon. For example, the parent indole (6a) reacted with styrene oxide (7) to give good yields of $\mathbf{8 a}$ at room temperature in TFE, with only trace amounts of the trifluoroethoxy byproduct 9 (entry 1 ). This reaction proceeded more rapidly and cleanly at reflux (entry 2). The corresponding reaction of 6 a in aqueous acetone or aqueous ethanol solvent gave lower yield of product $\mathbf{8 a}$, and required significantly longer reaction times (entries 3,4 ). Methyl-substituted indoles $\mathbf{6 b}$ and $\mathbf{6 c}$ also gave good yields of the corresponding alkylated products $\mathbf{8 b}$ and $\mathbf{8 c}$ in TFE (entries $5-7$ ) vs. other solvents (entries 8, 9). However, electron-withdrawing substituents on the indole diminished nucleophilicity, so that 5-bromoindole $6 \mathbf{d}$ required 72 hours for partial conversion, with the yield of $\mathbf{8 d}$ diminished by the competing reaction of TFE with the epoxide (entry 10).

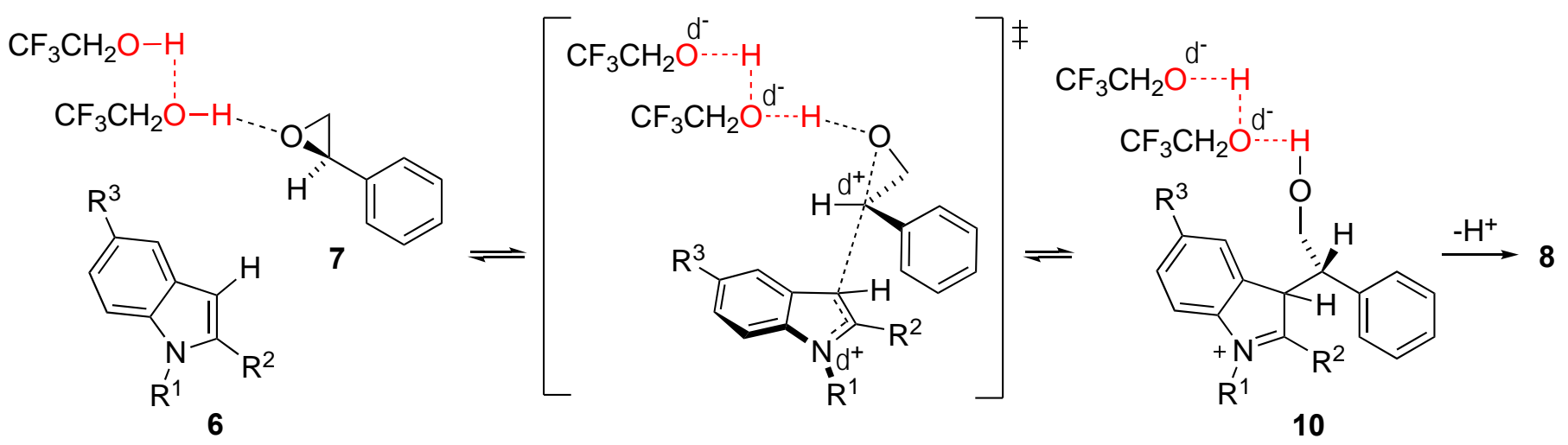

Figure 3. The electrophilic aromatic alkylation mechanism promoted by hydrogen bonding and the ionizing power of TFE. 
Table 3. TFE-promoted alkylations of indoles 6 with $(R)$-styrene oxide (7)<smiles>[R]c1ccc2c(c1)-c1cc([R])n([R])c1-2</smiles>

6a $R^{1}, R^{2}, R^{3}=H$ 6b $\mathrm{R}^{1}=\mathrm{CH}_{3} ; \mathrm{R}^{2}, \mathrm{R}^{3}=\mathrm{H}$ 6c $\mathrm{R}^{1}, \mathrm{R}^{2}=\mathrm{CH}_{3} ; \mathrm{R}^{3}=\mathrm{H}$ 6d $R^{1}, R^{2}=H ; R^{3}=B r$<smiles>[R]c1ccc2c(c1)c([C@H](CO)c1ccccc1)c([R])n2[R]</smiles>

8a $R^{1}, R^{2}, R^{3}=H$<smiles>OCC(OCC(F)(F)F)c1ccccc1</smiles>

9
7

8b $\mathrm{R}^{1}=\mathrm{CH}_{3} ; \mathrm{R}^{2}, \mathrm{R}^{3}=\mathrm{H}$

8c $R^{1}, R^{2}=\mathrm{CH}_{3} ; \mathrm{R}^{3}=\mathrm{H}$

8d $R^{1}, R^{2}=H ; R^{3}=B r$

\begin{tabular}{|c|c|c|c|c|c|c|}
\hline entry & indole & solvent & temperature $\left({ }^{\circ} \mathrm{C}\right)$ & time $(\mathrm{h})$ & yield 8 (\%) & yield $9(\%)$ \\
\hline 1 & $6 a$ & TFE & 20 & 48 & 65 & trace \\
\hline 2 & $6 a$ & TFE & 80 & 10 & 79 & - \\
\hline 3 & $6 a$ & acetone : $\mathrm{H}_{2} \mathrm{O}(80: 20)$ & 60 & 72 & 9 & \\
\hline 4 & $6 a$ & ethanol : $\mathrm{H}_{2} \mathrm{O}(40: 60)$ & 80 & 72 & 45 & \\
\hline 5 & $6 b$ & TFE & 80 & 4 & 73 & - \\
\hline 6 & $6 c$ & TFE & 20 & 24 & 77 & - \\
\hline 7 & $6 c$ & TFE & 80 & 3 & 90 & - \\
\hline 8 & $6 c$ & acetone : $\mathrm{H}_{2} \mathrm{O}(80: 20)$ & 60 & 14 & 17 & \\
\hline 9 & $6 c$ & ethanol: $\mathrm{H}_{2} \mathrm{O}(40: 60)$ & 80 & 12 & 54 & \\
\hline 10 & $6 d$ & TFE & 80 & 72 & 45 & 19 \\
\hline
\end{tabular}

The regioselectivity and stereospecificity outcomes were consistent with the fluorinated alcohol solvent stabilizing partial positive charge on the benzylic position in the transition state for the alkylation reaction (Figure 3).

Westermaier and Mayr established that the scope of epoxide substrates with indoles was relatively limited: the reaction of $\mathbf{6 c}$ with trans-stilbene oxide (11) provided $\mathbf{1 3}$ in good yield, but the corresponding reaction with cis-stilbene oxide (12) proceeded slowly-albeit with stereospecificity-to generate the expected diastereomer 14 (Scheme 2). The aliphatic epoxide 1,2-epoxyhexane (15) underwent indole alkylation only sluggishly, at the unsubstituted carbon, to produce 16, with the competing addition of TFE giving byproduct 17 . 
<smiles>Cc1c(C)n(C)c2ccccc12</smiles>

6c $\quad( \pm)-11$

( \pm -13, 66\% yield<smiles>[O-][C+]([O-])[O-]</smiles>

12

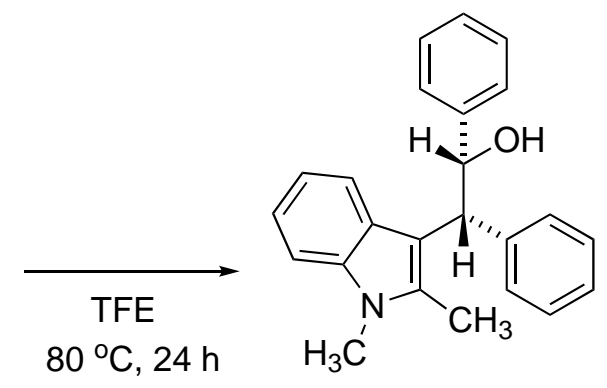

(士)-14, 17\% yield<smiles>CCCCC1CO1</smiles>

$( \pm)-15$
TFE $80^{\circ} \mathrm{C}, 48 \mathrm{~h}$<smiles>CCCCC(O)Cc1c(C)n(C)c2ccccc12</smiles>

$\mathrm{H}_{3} \mathrm{C}$<smiles>CCCCC(O)COCC(F)(F)F</smiles>

$17,28 \%$ yield

Scheme 2. Representative scope of epoxide substrates in TFE-promoted alkylations of indoles.

Sun, Hong, and Wang extended the alkylation of indole (6a) to spiroepoxyoxindole 18 , exploring several conditions with fluorinated alcohol solvents (Table 4). ${ }^{33}$ TFE promoted the reaction even at room temperature (entry 1), with a better yield and shorter reaction time upon warming (entry 2). The more acidic and highly ionizing solvent HFIP gave a considerably faster reaction, albeit with a slight loss of regioselectivity (entry 3 ). However, selectivity was regained in water containing some HFIP (9:1 ratio) to provide 19 in excellent yield, with carbon-carbon bond-formation at the more substituted position (entry 4). Other organic solvents such as dichloromethane, dimethyl sulfoxide, methanol, tetrahydrofuran, or toluene did not give product 19. 
Table 4. Comparing the effects of TFE vs. HFIP and water on alkylation with spiroepoxyoxindole (18)

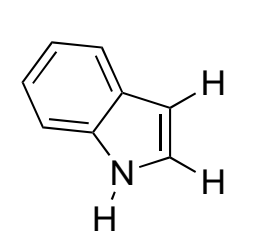

6a (3 equiv)

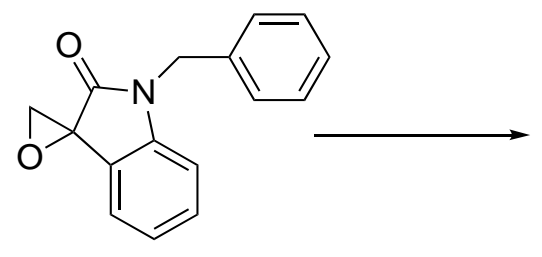

$( \pm)-18$

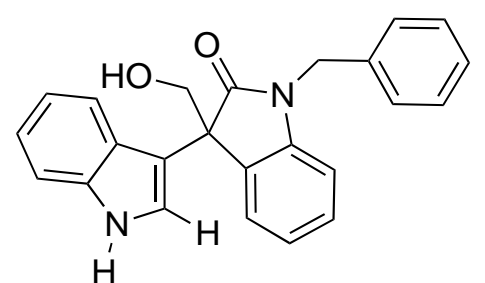

$( \pm)-19$

\begin{tabular}{ccccc}
\hline entry & solvent & temperature $\left({ }^{\circ} \mathrm{C}\right)$ & time $(\mathrm{h})$ & yield 19 (\%) \\
\hline 1 & TFE & 25 & 80 & 65 \\
2 & TFE & 60 & 32 & 90 \\
3 & HFIP & 25 & 12 & $66^{\mathrm{a}}$ \\
4 & $\mathrm{H}_{2} \mathrm{O} / \mathrm{HFIP}(9: 1)$ & 25 & 32 & 93 \\
\hline
\end{tabular}

a $15: 1$ regioisomer ratio.

Westermaier and Mayr also described alkylations of pyrroles with styrene oxide (7) in TFE, affording regioisomer mixtures and double alkylation products with simpler pyrroles. Conversely, 1,2,5-trimethylpyrrole (20) selectively produced $\mathbf{2 1}$ as its major product (Scheme 3). ${ }^{32} \mathrm{Li}$ and Qu subsequently reported alkylation of 1,3,5-trimethoxybenzene (22) in HFIP, with the electron-rich aromatic compound out-competing the HFIP solvent to favor the aromatic alkylation product $\mathbf{2 3}$ over the solvent addition product $\mathbf{2 4} .{ }^{34}$ Chiral non-racemic styrene oxide $(R)-\mathbf{7}$ stereospecifically led to both products $\mathbf{2 1}$ and 23, with inversion of configuration. The yields were substantially lower with 1,4-dimethoxybenzene (35\%) and with anisole (15\%).

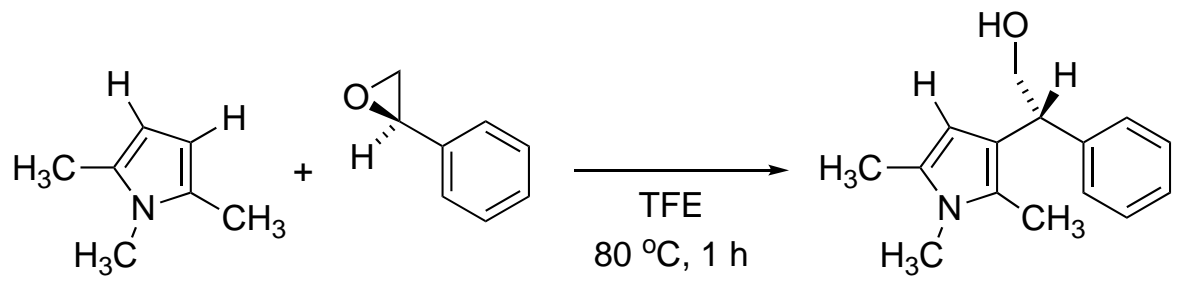

20

7<smiles>COc1cc(OC)cc(OC)c1</smiles>

22 (5 equiv)<smiles>c1ccc([C@H]2CO2)cc1</smiles>

7
21, $74 \%$ yield<smiles></smiles>

23, $61 \%$ yield
24, 30\% yield

Scheme 3. Alkylations of other electron-rich aromatic compounds with (R)-styrene oxide (7).

The three-atom + two-atom annulations of epoxides with alkenes to form tetrahydrofurans have typically required transition metal catalysts, likely operating by radical or Lewis acid processes. ${ }^{35,36}$ However, Llopis and Baeza have reported catalyst-free conditions, simply by warming in HFIP solvent. ${ }^{37}$ Although the scope is limited to aryl-substituted epoxides, the yields are modest, and the diastereoselectivity is generally low, metal-catalyzed versions of this transformation also share these limitations. ${ }^{35,36}$ The reactions of styrene (25) 
and alpha-methylstyrene (26) with racemic styrene oxide (7) in HFIP solvent exemplify these results (Scheme 4). With chiral non-racemic styrene oxide $(R)-\mathbf{7}$, the reaction with styrene (25) gives racemic product 27 , whereas only partial racemization occurs upon forming tetrahydrofuran $\mathbf{2 8}$ from alpha-methylstyrene (26) (not shown). Annulations with ethyl 3-methyl-3-phenylglycidate (30), commercially available as a mixture of diastereomers, give higher diastereoselectivities upon reaction with styrene (25) and 1,1-diphenylethene (29). The regioselectivity is consistent with the less substituted carbon of the alkene adding to the phenylsubstituted carbon of the epoxide, with carbon-oxygen bond formation at the phenyl-substituted carbon arising from the alkene reactant. The yields of tetrahydrofuran products are diminished by competing dimerizations and trimerizations of the aryl alkene, ${ }^{38}$ and solvent addition to the epoxide, forming byproducts including ether $\mathbf{2 4}$ (see Scheme 3 for structure).

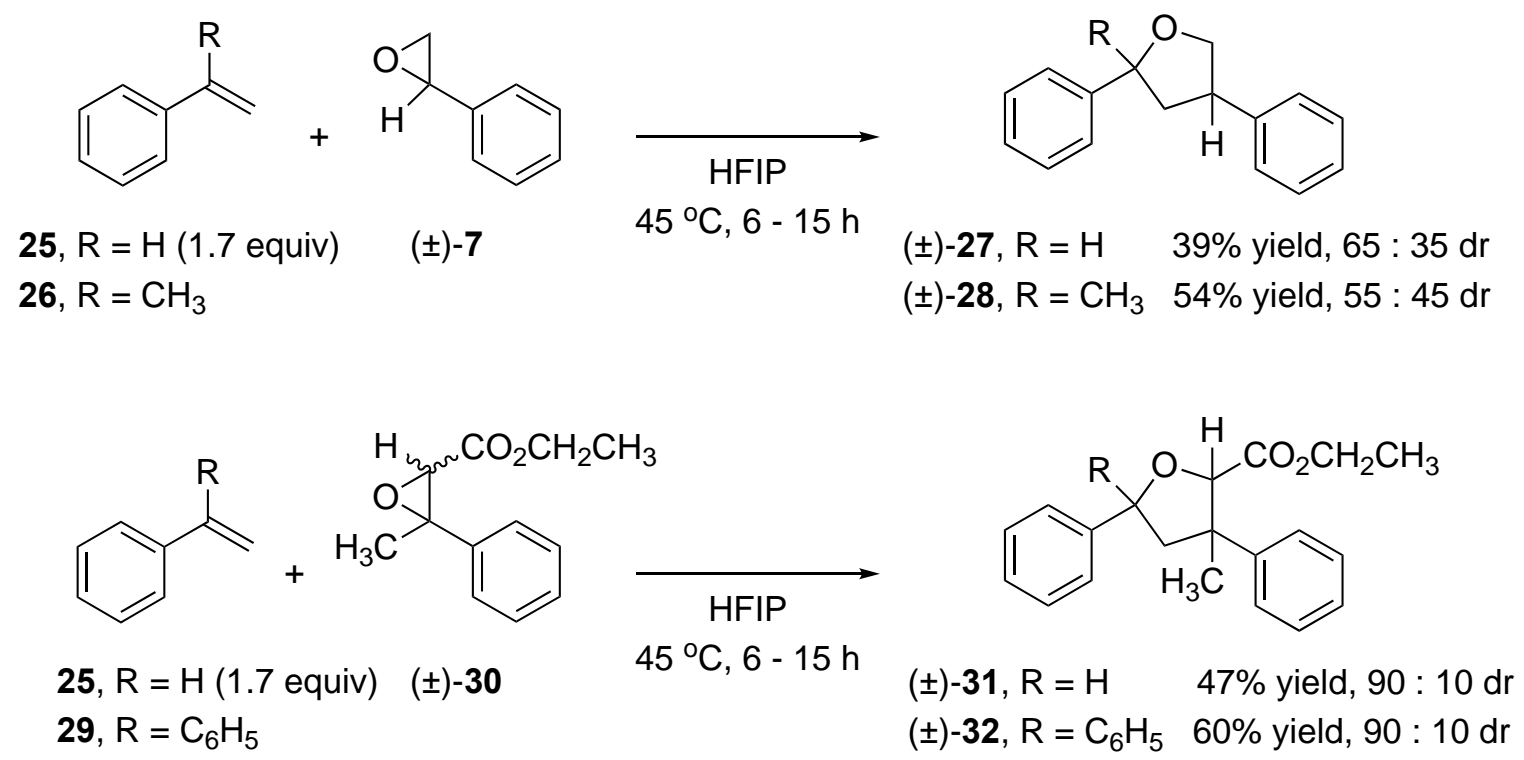

Scheme 4. Three-atom + two-atom annulations of aryl-substituted epoxides with aryl alkenes.

\subsection{Intramolecular carbon-carbon bond-forming reactions}

$\mathrm{Li}$ and $\mathrm{Qu}$ reported the intramolecular alkylation of epoxides tethered to electron-rich aromatic rings, using fluorinated alcohol solvents to activate the epoxide. ${ }^{34}$ Although the literature includes several Lewis acidcatalyzed methods for the cycloisomerization of $\mathbf{3 3}$ to $\mathbf{3 4}$, these workers explored the effects of highly ionizing solvents in the absence of Lewis acids (Table 5). In contrast to methanol or water (entries 1, 2), TFE promoted cyclization in excellent yield (entries 3,4). HFIP was an even more effective promoter, affording the cyclized product in only five minutes at reflux (entries 5,6 ). Nucleophilic addition occurred with high regioselectivity for the 6-endo-mode of cyclization, and with inversion of configuration at the benzylic carbon to provide the trans-disubstituted benzopyran $\mathbf{3 4}$ from the trans-disubstituted epoxide $\mathbf{3 3}$. The significant decrease in reaction time between TFE and HFIP is consistent with the increased acidity and ionizing power of HFIP, rather than hydrogen bond donation, which diminishes at higher temperature. ${ }^{39,40}$ 
Table 5. Solvent screening for cycloisomerization of epoxide $\mathbf{3 3}$<smiles>COc1cc(OC)cc(OC[C@H](O)c2ccccc2)c1</smiles>

\begin{tabular}{ccccc}
\hline entry & solvent & temperature $\left({ }^{\circ} \mathrm{C}\right)$ & time & yield 34 (\%) \\
\hline 1 & methanol & 65 & $26 \mathrm{~h}$ & 18 \\
2 & water & 100 & $10 \mathrm{~h}$ & $55^{\mathrm{a}}$ \\
3 & TFE & 20 & $48 \mathrm{~h}$ & 96 \\
4 & TFE & 74 & $4.5 \mathrm{~h}$ & 99 \\
5 & HFIP & 20 & $4 \mathrm{~h}$ & 99 \\
6 & HFIP & 59 & $5 \mathrm{~min}$ & 99 \\
\hline
\end{tabular}

a remainder was diol from epoxide hydrolysis.

The epoxide substrate $\mathbf{3 5}$ with an acid-sensitive benzylic ether, provided a valuable demonstration of the power of this HFIP-promoted transformation (Scheme 5). The previous synthesis of compound 36, closely corresponding to the catechin natural products, required a specialized combination of Lewis acid and hydrogen bond donor catalysts $\left(\mathrm{AuCl}_{3} / \mathrm{AgOTf} /\right.$ thiourea). ${ }^{41}$ In contrast, HFIP solvent promoted the slow but clean conversion of epoxide $\mathbf{3 5}$ into benzopyranol 36, arising from 6-endo-mode nucleophilic addition to the unsubstituted carbon of the epoxide. ${ }^{34}$<smiles>COc1cc(OC)cc(O[C@H](c2ccccc2)[C@H]2CO2)c1</smiles>

35<smiles>COc1cc(OC)c2c(c1)O[C@H](c1ccccc1)[C@H](O)C2</smiles>

$36,51 \%$ yield

Scheme 5. HFIP-promoted cyclization of the sensitive epoxy-ether 35.

The Magauer laboratory reported the acid-catalyzed cycloisomerizations of neopentyl epoxides tethered to electron-rich aromatic rings. ${ }^{42}$ In the course of cyclization of substrate $\mathbf{3 7}$ to tetralin product $\mathbf{3 8}$, a methyl group underwent 1,2-alkyl shift. Cyclizations were unsuccessful or proceeded in low yield in most solvents (Table 6, entry 1 for a representative example) but improved in fluorinated alcohol solvents, with HFIP outperforming TFE (entries 2 vs. 3). The optimized conditions used sulfuric acid in HFIP at $0{ }^{\circ} \mathrm{C}$ (entry 5). HFIP forms hydrogen bonds with the conjugate base of sulfuric acid, increasing its Brønsted acid activity. ${ }^{43}$ 
Table 6. Acid-catalyzed, HFIP-promoted cycloisomerization of neopentyl epoxide 37

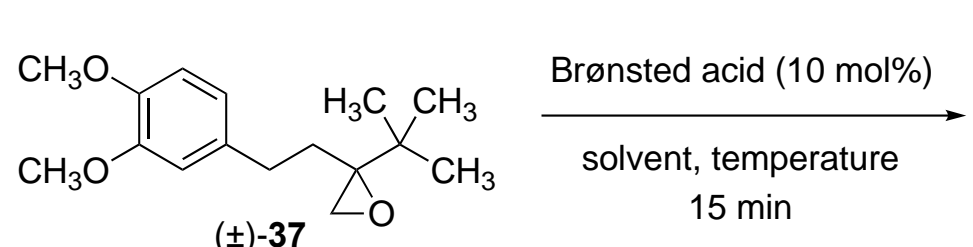

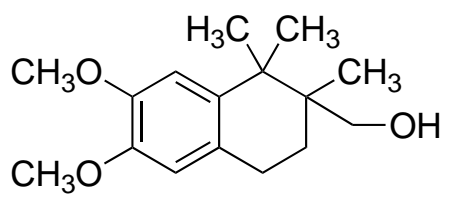

$( \pm)-38$

\begin{tabular}{ccccc}
\hline entry & Brønsted acid & solvent & temperature & yield 38 (\%) $)^{\mathrm{a}}$ \\
\hline 1 & $\mathrm{H}_{2} \mathrm{SO}_{4}$ & toluene & $23^{\circ} \mathrm{C}$ & $19 \%$ \\
2 & $\mathrm{H}_{2} \mathrm{SO}_{4}$ & $\mathrm{TFE}$ & $23^{\circ} \mathrm{C}$ & $43 \%$ \\
3 & $\mathrm{H}_{2} \mathrm{SO}_{4}$ & $\mathrm{HFIP}$ & $23^{\circ} \mathrm{C}$ & $77 \%$ \\
4 & $p$-toluenesulfonic acid & $\mathrm{HFIP}$ & $23^{\circ} \mathrm{C}$ & $77 \%$ \\
5 & $\mathrm{H}_{2} \mathrm{SO}_{4}$ & $\mathrm{HFIP}$ & $0{ }^{\circ} \mathrm{C}$ & $83 \%$ \\
\hline
\end{tabular}

a ${ }^{1} \mathrm{H}$ NMR yields. ${ }^{\mathrm{b}}$ The isolated yield of compound 38 was $80 \%$.

The phenyl substrate 39a also produced the corresponding tetralin 40a (Table 7, entry 1 ). ${ }^{42}$ The reaction conditions tolerated aryl ether tethers in $39 \mathrm{~b}$ to form chromane $40 \mathrm{~b}$ (entry 2 ). With electron-donating substituents, cycloisomerization favored the para-isomers $40 \mathrm{c}-\mathbf{d}$ with varying levels of regioselectivity (entries $3,4)$. Aromatic rings with strongly electron-withdrawing substituents gave lower yields or did not cyclize.

Table 7. Alkyl vs. ether tethers, and regioselectivity of monomethoxy aromatic substrates

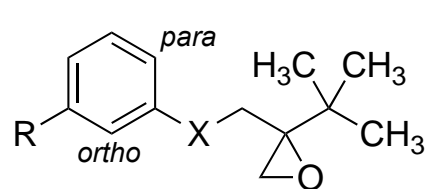

39a $\mathrm{R}=\mathrm{H} ; \mathrm{X}=\mathrm{CH}_{2}$

39b $\mathrm{R}=\mathrm{H} ; \mathrm{X}=\mathrm{O}$

39c $\mathrm{R}=\mathrm{CH}_{3} \mathrm{O} ; \mathrm{X}=\mathrm{CH}_{2}$

39d $\mathrm{R}=\mathrm{CH}_{3} \mathrm{O} ; \mathrm{X}=\mathrm{O}$

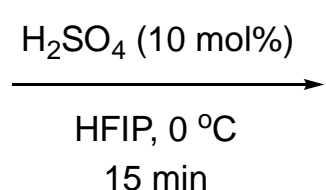

$15 \mathrm{~min}$<smiles>[X]c1cccc2c1CC(C)(CO)C2(C)C</smiles>

40a $\mathrm{R}=\mathrm{H} ; \mathrm{X}=\mathrm{CH}_{2}$

40b $\mathrm{R}=\mathrm{H} ; \mathrm{X}=\mathrm{O}$

40c $\mathrm{R}=\mathrm{CH}_{3} \mathrm{O} ; \mathrm{X}=\mathrm{CH}_{2}$

40d $\mathrm{R}=\mathrm{CH}_{3} \mathrm{O} ; \mathrm{X}=\mathrm{O}$

\begin{tabular}{cccc}
\hline entry & substrate & yield $\mathbf{4 0}(\%)$ & regioselectivity \\
\hline 1 & 39a & $70 \%$ & n. a. \\
2 & 39b & $60 \%$ & n. a. \\
3 & 39c & $69 \%$ & para only \\
4 & 39d & $40 \%$ & para $:$ ortho $=4.7: 1^{\text {a }}$ \\
\hline
\end{tabular}

a ortho-isomer not shown.

Neopentyl epoxide substrates containing cycloalkyl rings showed divergent behavior, depending on the degree of ring strain (Table 8 ). ${ }^{42}$ The cyclobutyl and cyclopentyl substrates $\mathbf{4 1 a - 4 1 b}$ favored the corresponding ring-expansion fused products $\mathbf{4 2 a}$ and $\mathbf{4 2}$ b (entries 1,2 ), whereas the cyclohexyl substrate $\mathbf{4 1 c}$ produced exclusively the spiro isomer $\mathbf{4 3 c}$ arising from a 1,2-methyl shift. 
Table 8. Cycloisomerizations of methylcycloalkyl epoxide substrates $\mathbf{4 1}$

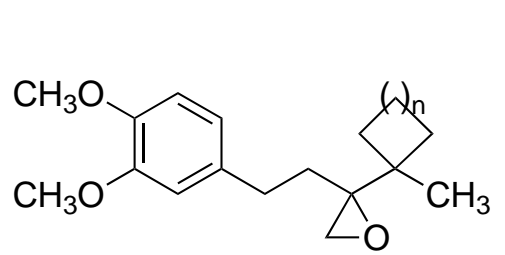

$41 \mathrm{a} n=1$

$41 \mathrm{~b} n=2$

41c $\mathrm{n}=3$

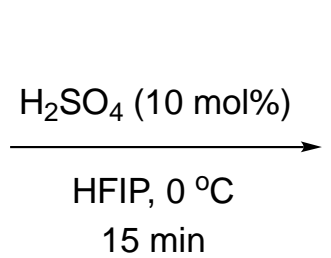

$15 \min$

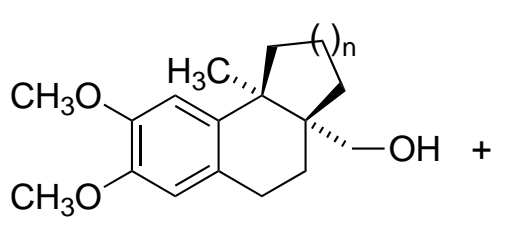

42a $\mathrm{n}=1$

$42 b \quad n=2$

42c $n=3$<smiles>C=CC1(C)CCC(C)(CO)c2cc(OC)c(OC)cc21</smiles>

$43 a n=1$

43b $\mathrm{n}=2$

43c $n=3$

\begin{tabular}{cccc}
\hline entry & substrate $^{\mathrm{a}}$ & ${\text { yield } \mathbf{4 2}(\%)^{\mathrm{a}}}$ & ${\text { yield } \mathbf{4 3}(\%)^{\mathrm{a}}}^{\mathrm{a}}$ \\
\hline 1 & $\mathbf{4 1 a}$ & 76 & 0 \\
2 & 41b & 54 & 6 \\
3 & 41c & 0 & 71 \\
\hline
\end{tabular}

${ }^{a}$ substrates and products are racemic.

The partitioning of mechanistic pathways leading to products $\mathbf{4 2}$ and $\mathbf{4 3}$ is consistent with carbenium ion intermediates. ${ }^{42}$ As depicted in Figure 4, ring expansion exclusively occurs (path a) with strained cyclobutyl epoxide 41a and is favored with cyclopentyl epoxide 41b. With the unstrained cyclohexane attached to epoxide 41c, the 1,2-methyl shift (path b) exclusively occurs. From each tertiary carbenium ion intermediate 44 and 45, intramolecular Friedel-Crafts alkylation provides the tetralin core structures of products $\mathbf{4 2}$ and $\mathbf{4 3 .}$ Figure 4 also depicts the hydrogen bonding interaction between HFIP and sulfuric acid, and HFIP stabilization of the hydrogen sulfate conjugate base, ${ }^{43}$ which is also observed in other acid-catalyzed processes. ${ }^{44,45}$

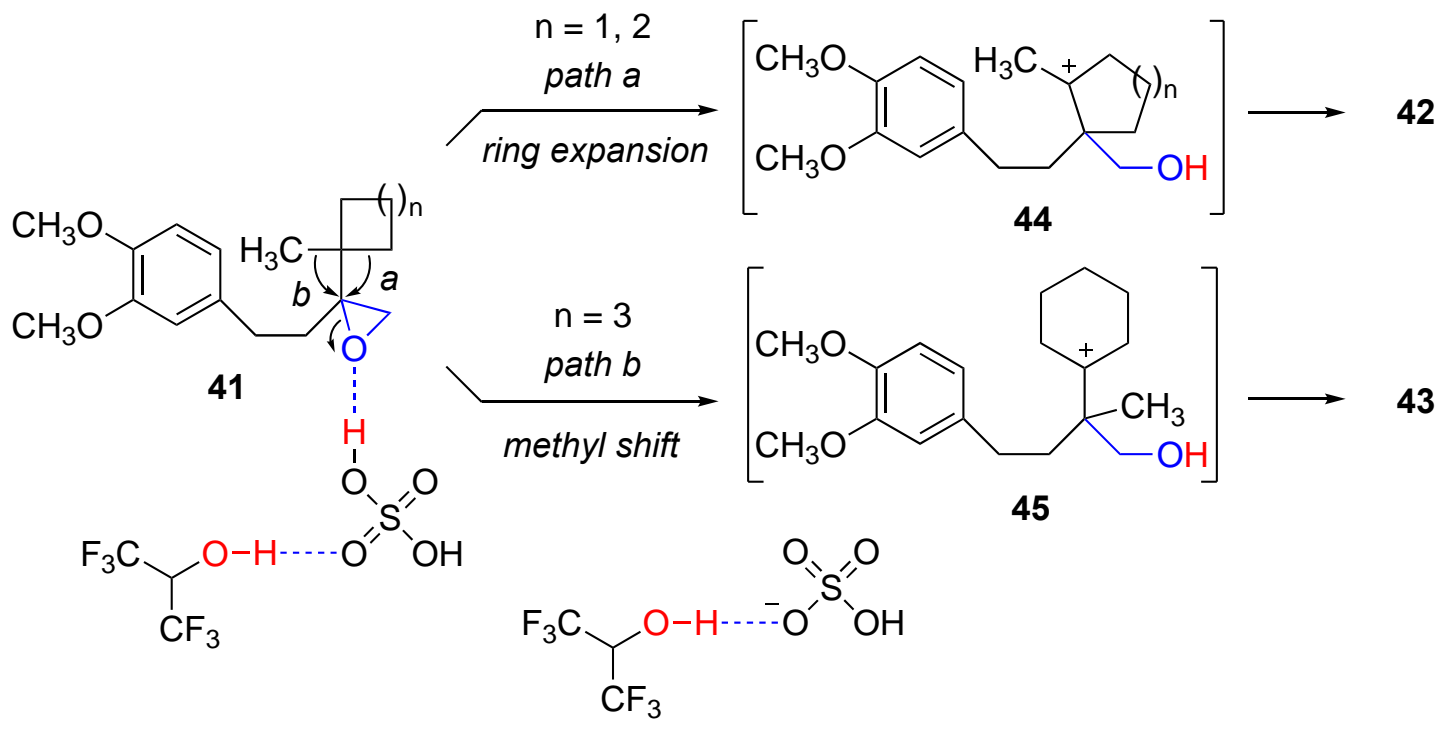

Figure 4. Possible mechanisms for cycloisomerization.

Biomimetic polyene-epoxide polycyclizations have typically required Lewis acid promoters or catalysts. ${ }^{46,47}$ In contrast, the Qu laboratory observed slow conversion of epoxydiene $\mathbf{4 6}$ when dissolved in HFIP, producing a mixture of tetracyclic product 47, the oxabicyclo[2.2.1] heptane byproduct 48, and an inseparable mixture of partially cyclized dienes 49 (Table 9, entry 1). ${ }^{48}$ Remarkably, epoxydiene 46 was inert in other fluorinated 
alcohol solvents (entries 2,3 ). $p$-Toluenesulfonic acid ( $p$-TSA) rapidly catalyzed the reaction of 46 , but gave a mixture favoring the partially cyclized byproducts 49 (entry 4). The reaction rate dramatically increased, with improved selectivity for tetracyclic product 47, upon gradual addition of epoxydiene $\mathbf{4 6}$ to HFIP solutions of soluble organic salts with fluorine-containing non-nucleophilic anions (entries 5 - 7). Tetraphenylphosphonium tetrafluoroborate $\left(\mathrm{Ph}_{4} \mathrm{PBF}_{4}\right)$ in HFIP gave the best yield of compound 47 (entry 7). Although excess water hydrolyzed the epoxide of $\mathbf{4 6}$ to form a diol, up to 20 equivalents of water were compatible with tricyclization (entry 8). Deliberately adding catalytic hydrogen fluoride to HFIP gave a similar enhancement in the reaction rate (entry 9), supporting a proposal that $\mathrm{BF}_{4}^{-}$and $\mathrm{PF}_{6}^{-}$provided trace amounts of HF. However, replacing HFIP with dichloromethane, while including $\mathrm{Ph}_{4} \mathrm{PBF}_{4}$ and $\mathrm{HF}$ as additives, gave no reaction (entry 10). The authors concluded that HFIP played an essential role in promoting the polycyclization, likely by stabilizing the fluoride conjugate base.

Table 9. HFIP / additive-promoted tricyclizations of epoxydiene 46<smiles>CC(=CCCc1ccccc1)CCCC(C)=CCCC1OC1(C)C</smiles>

$( \pm)-46$

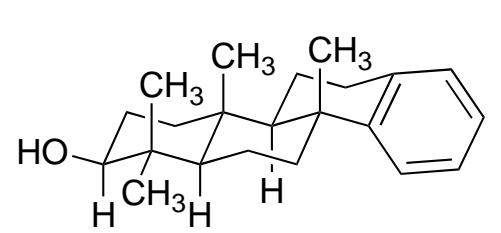

$( \pm)-47$

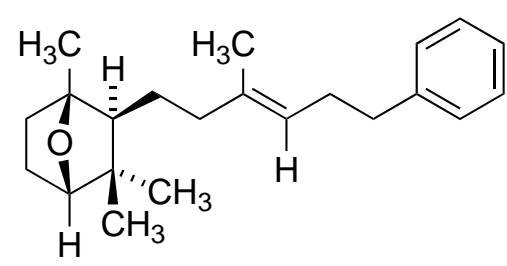

$( \pm)-48$

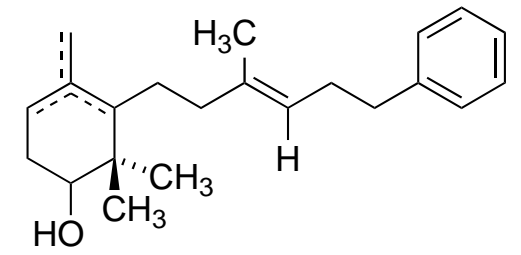

$( \pm)-49$

\begin{tabular}{|c|c|c|c|c|c|c|}
\hline entry & solvent & additive(s) & time & yield 47 (\%) & yield 48 (\%) & yield 49 (\%) \\
\hline 1 & HFIP & none & $24 \mathrm{~h}$ & 40 & 27 & 32 \\
\hline 2 & TFE & none & $24 \mathrm{~h}$ & (no reaction) & & \\
\hline 3 & $\left(\mathrm{CF}_{3}\right)_{3} \mathrm{COH}$ & none & $24 \mathrm{~h}$ & (no reaction) & & \\
\hline 4 & $\mathrm{CH}_{2} \mathrm{Cl}_{2}$ & $p$-TSA ( 0.1 equiv) & $15 \mathrm{~min}$ & 23 & 19 & 56 \\
\hline 5 & HFIP & $\mathrm{Bu}_{4} \mathrm{~N}^{+} \mathrm{BF}_{4}^{-}(0.1 \mathrm{M})$ & $5 \min$ & 51 & n.r. ${ }^{a}$ & n.r. \\
\hline 6 & HFIP & $\mathrm{Bu}_{4} \mathrm{~N}^{+} \mathrm{PF}_{6}^{-}(0.1 \mathrm{M})$ & $5 \mathrm{~min}$ & 51 & n.r. & n.r. \\
\hline 7 & HFIP & $\mathrm{Ph}_{4} \mathrm{P}^{+} \mathrm{BF}_{4}^{-}(0.1 \mathrm{M})$ & $5 \mathrm{~min}$ & 60 & 19 & n.r. \\
\hline 8 & HFIP & $\begin{array}{c}\mathrm{Ph}_{4} \mathrm{P}^{+} \mathrm{BF}_{4}^{-}(0.1 \mathrm{M})+ \\
\mathrm{H}_{2} \mathrm{O}(0.2 \mathrm{M})\end{array}$ & $5 \mathrm{~min}$ & 56 & n.r. & n.r. \\
\hline 9 & HFIP & HF (0.001 M) & $5 \min$ & 37 & n.r. & n.r. \\
\hline 10 & $\mathrm{CH}_{2} \mathrm{Cl}_{2}$ & $\begin{array}{c}\mathrm{Ph}_{4} \mathrm{P}^{+} \mathrm{BF}_{4}^{-}(0.1 \mathrm{M})+ \\
\mathrm{HF}(0.001 \mathrm{M})\end{array}$ & $24 \mathrm{~h}$ & (no reaction) & & \\
\hline
\end{tabular}

a n.r. = not reported

These scientists then applied these conditions to the cyclization of squalene oxide (50), the biosynthetic precursor of lanosterol and other steroid natural products (Scheme 6). ${ }^{48}$ The 36\% yield of tricyclic product $\mathbf{5 2}$ was substantially higher than the outcomes from various Lewis acid-promoted transformations. ${ }^{49-53}$ The 
formation of compound $\mathbf{5 2}$ is consistent with a mechanism involving concerted cyclization of the three alkenes closest to the epoxide, thereby generating a tertiary carbenium ion $\mathbf{5 1}$. The authors proposed that the cations - including protonated epoxide and the tricyclic intermediate cation $\mathbf{5 1}$ - were stabilized by the nonnucleophilic solvent HFIP and/or the non-nucleophilic tetrafluoroborate anions. From 51, an intramolecular cascade of face-selective 1,2-hydride and 1,2-methyl migrations followed by deprotonation generated the principal product 52.<smiles>CC=C(C)CC/C=C(\C)CC/C=C(\C)CC/C=C(\C)CCCC1OC1(C)C</smiles>
$( \pm)-50$

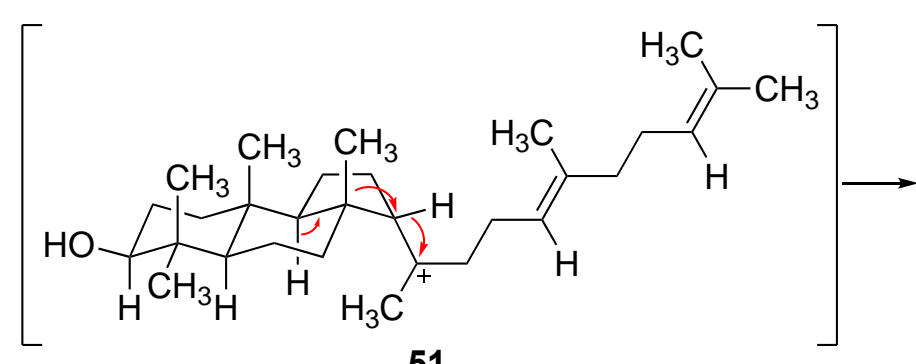

51

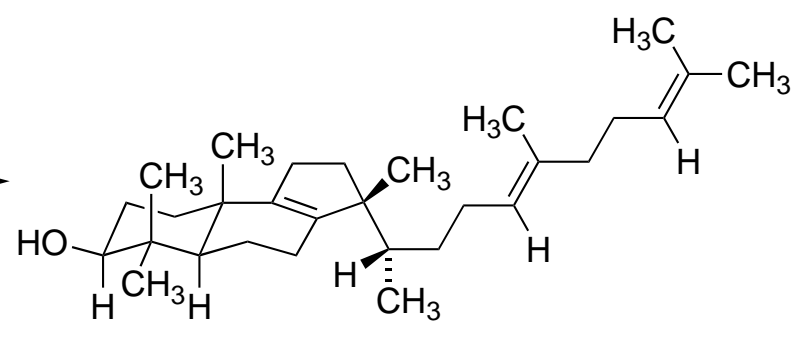

$( \pm)-52,36 \%$ yield<smiles>CC(C)=CCC/C(C)=C/CC/C(C)=C/CC/C(C)=C/[13CH2][13CH2][13CH3]</smiles>

Scheme 6. HFIP / $\mathrm{Ph}_{4} \mathrm{PBF}_{4}$-promoted cyclization of squalene oxide (50).

In summary, although most epoxide alkylations are limited to electron-rich aromatic compounds, fluorinated alcohol solvents effectively replaced the Lewis acidic reagents and catalysts customarily used for these transformations. The intramolecular alkylations of epoxides tethered to polyenes have demonstrated the powerful combination of additive Brønsted acid sources in combination with HFIP.

\section{Ring-opening Reactions with Organopalladium Intermediates arising from Directed C-H Functionalization}

Directed C-H functionalization of aromatic rings has traditionally required strongly basic reagents, such as tertbutyllithium combined with $N, N, N, N$-tetramethylethylenediamine (TMEDA). Regioselectivity ortho- to a Lewis basic directing group (DG) arises from coordination with the electropositive metal, bringing the electronegative alkyl ligand into proximity to the aromatic $\mathrm{C}-\mathrm{H}$ bond. ${ }^{54,55}$ The resulting functionalized aryllithium intermediates react with many electrophiles, and the literature documents several examples with epoxides. ${ }^{56}$ However, transition-metal catalysts offer milder conditions for directed $\mathrm{C}-\mathrm{H}$ functionalization. The literature provides several examples in which HFIP has favored palladium acetate-catalyzed directed metalations of benzene rings, coupled with in situ alkylation of epoxides, presumably also activated by HFIP 
for nucleophilic addition (Figure 5). ${ }^{57-61}$ A variety of Lewis basic directing groups (DG) are effective, including 2pyridyl (54), and a variety of carbonyl- or carboxyl-derived compounds 55 - 59.

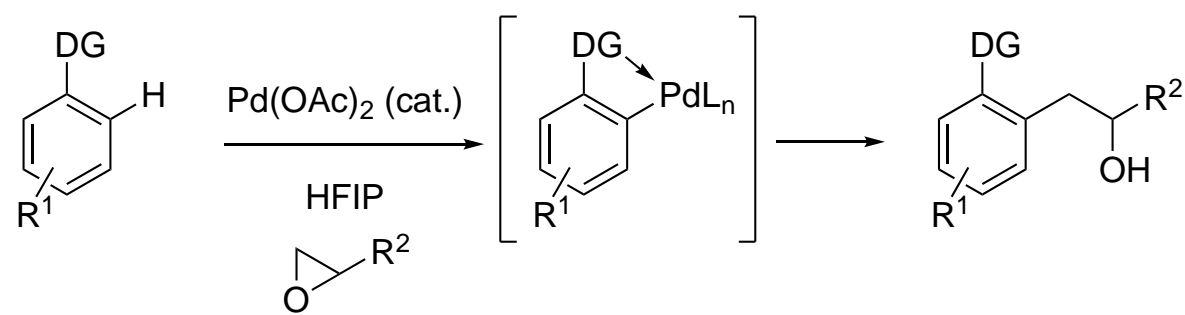

Directing groups (DG) include:

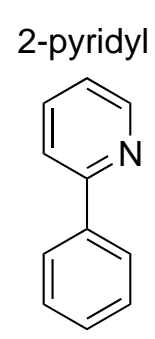

54

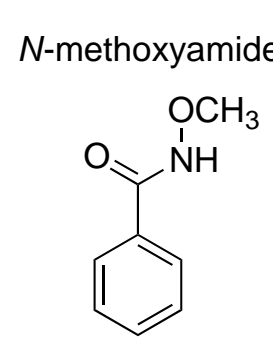

55

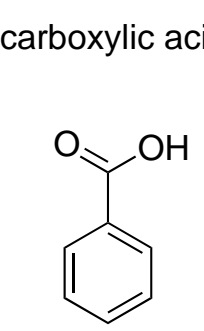

56

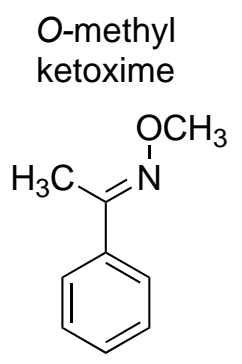

57 amide<smiles>CC(=O)Nc1ccccc1</smiles>

58
$\mathrm{N}, \mathrm{N}$-dimethylurea<smiles>CN(C)C(=O)Nc1ccccc1</smiles>

59

Figure 5. Directing groups for palladium acetate-catalyzed C-H functionalization / epoxide alkylation.

The methods published to date have several common features:

- All use palladium acetate as the catalyst,

- The methods show broad scope with many substituents $\mathrm{R}^{1}$ on the benzene ring, and

- A variety of monosubstituted and 1,1-disubstituted epoxides give good yields (Figure 6).<smiles>c1ccc(OCC2CO2)cc1</smiles>

60<smiles>c1ccc(COCC2CO2)cc1</smiles>

61<smiles>c1ccc(CC2CO2)cc1</smiles>

62<smiles>COC(=O)C1CO1</smiles>

63<smiles>COC(=O)C1(C)CO1</smiles>

64

Figure 6. Representative epoxides for palladium-catalyzed C-H functionalization / epoxide alkylation.

These methods also share common substrate limitations:

- To date, heterocyclic aromatic rings are not functionalized under these conditions, and

- 1,2-Disubstituted epoxides generally do not react, or give substantially lower yields.

- No examples have been reported with styrene oxide (7) or other arylepoxides.

\subsection{Scope of reactions and conditions}

In 2015, the Kuninobu and Kanai laboratories collaboratively reported the regioselective alkylation of 2phenylpyridine (54) and derivatives with epoxides including phenyl glycidyl ether (60), catalyzed by palladium acetate (Scheme 7). ${ }^{57}$ The initial solvent choice, acetic acid, gave low yields due to acid-promoted decomposition of the epoxide. Diluting acetic acid with HFIP resulted in the substituted phenethyl alcohol 65 in excellent yield, provided that two equivalents of epoxide were used at room temperature, as the epoxide 
decomposed under these conditions at higher temperatures. These workers established that HFIP alone was not sufficient to promote this transformation. In addition to the $\mathbf{5 4}$ and $\mathbf{6 0}$ example, they also reported the analogous transformation with the $N$-methoxyamide 66 and methyl glycidate (63). In this example, the lactone ring of product 67 is presumably formed via acid-catalyzed intramolecular transacylation after the carboncarbon bond-forming step.<smiles>O=C(O)OCC1CO1</smiles>

54<smiles>CONC(=O)c1ccc(C)cc1</smiles>

66

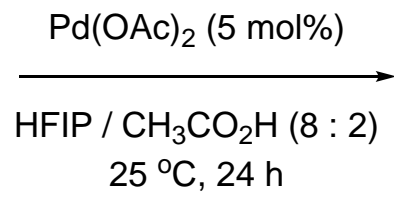
$\mathrm{Pd}(\mathrm{OAc})_{2}(10 \mathrm{~mol} \%)$
$\mathrm{HFIP} / \mathrm{CH}_{3} \mathrm{CO}_{2} \mathrm{H}(8: 2)$ $25^{\circ} \mathrm{C}, 36 \mathrm{~h}$

$67,68 \%$ yield

Scheme 7. Pd-catalyzed $\mathrm{C}-\mathrm{H}$ functionalization with 2-pyridyl and $\mathrm{N}$-methoxyamide directing groups, with regioselective epoxide alkylation.

Later in 2015, the Yu laboratory disclosed the directed alkylation of benzoic acids, including meta-toluic acid (68), with a broad scope of epoxide substrates (Scheme 8). ${ }^{58}$ Essential components of this reaction system included palladium acetate, potassium acetate, and HFIP solvent. Cesium acetate led to lower yields, and little or no product was formed when using sodium acetate or lithium acetate. Yields increased from $75 \%$ to $99 \%$ with the mono- $N$-protected amino acid ligand $N$-acetyl-tert-leucine. In a highly optimized example with benzyl glycidyl ether (61), product 69 was isolated in 99\% yield. At room temperature, the reaction proceeded more slowly and required higher catalyst loading, but produced intermediate hydroxyacid 70. This compound underwent HFIP-promoted lactonization at reflux to form 69. By avoiding acetic acid as a cosolvent, a broad range of epoxide substrates were compatible with HFIP, even under reflux. This carboxyl directing group method was compatible with cyclohexene oxide (71), producing trans-fused $\mathbf{7 2}$ in satisfactory yield. 


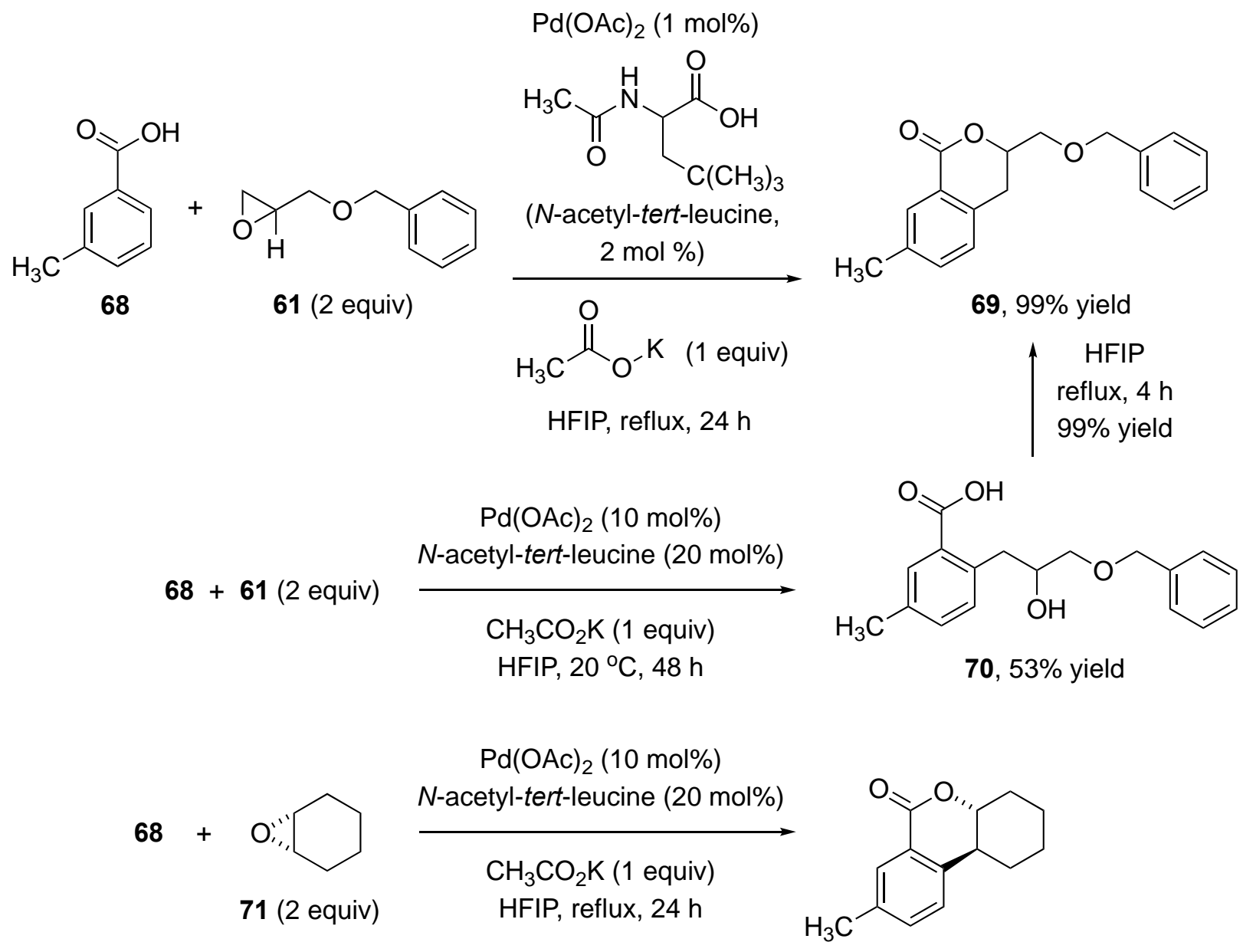

$( \pm)-72,55 \%$ yield

Scheme 8. Pd-catalyzed $\mathrm{C}-\mathrm{H}$ functionalization using a carboxylic acid directing group, with regioselective epoxide alkylation.

The Li laboratory optimized the directed alkylation of $O$-methyl ketoximes with epoxides, using HFIP and a carboxylic acid co-solvent. Pivalic acid gave much better yields than acetic acid. Neither HFIP nor pivalic acid alone were suitable solvents. The bicyclic substrate $\mathbf{7 3}$ with phenyl glycidyl ether (60, Scheme 9) afforded alcohol $74 .{ }^{59}$<smiles>CO/N=C1\CCOc2ccccc21</smiles>

73

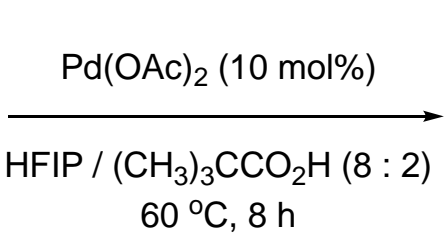

( \pm )-60 (2 equiv)<smiles>CON=C1CCOc2cccc(CC(O)COc3ccccc3)c21</smiles>

$( \pm)-74,89 \%$ yield

Scheme 9. Pd-catalyzed $\mathrm{C}-\mathrm{H}$ functionalization with an $\mathrm{O}$-methyl ketoxime directing group, promoting regioselective epoxide alkylation. 
In 2020, the Cheong and Lee laboratories collaboratively published the corresponding directed alkylations with equimolar amounts of epoxides, using $N$-acyl aniline derivatives as the directing groups, including acetanilide (58), the corresponding $N, N$-dimethylurea 59, and 1-phenylpyrrolidin-2-one (77) (Scheme 10). ${ }^{60}$ Notably, the Lewis basic oxygens of the directing groups were one atom further removed from the benzene carbon undergoing $\mathrm{C}-\mathrm{H}$ functionalization, yet the optimized conditions were similar to those reported for most of the other directing groups.<smiles>CC(=O)Nc1ccccc1</smiles>

58<smiles>c1ccc(OCC2CO2)cc1</smiles>

$( \pm)-60$

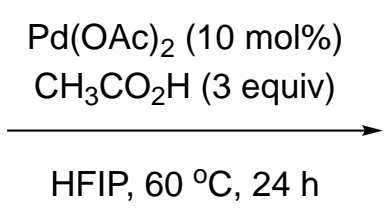

HFIP, $60^{\circ} \mathrm{C}, 24 \mathrm{~h}$<smiles>CN(C)C(=O)Nc1ccccc1</smiles>

59<smiles>O=C1CCCN1c1ccccc1</smiles>

77

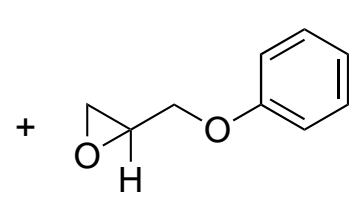

( \pm - 60
$\mathrm{Pd}(\mathrm{OAc})_{2}$ (10 mol\%) $\mathrm{CH}_{3} \mathrm{CO}_{2} \mathrm{H}$ (3 equiv)

HFIP, $60^{\circ} \mathrm{C}, 24 \mathrm{~h}$<smiles>CC(=O)Nc1ccccc1CC(O)COc1ccccc1</smiles>

$( \pm)-75,79 \%$ yield<smiles>CN(C)C(=O)Nc1ccccc1CC(O)COc1ccccc1</smiles>

$( \pm)-76,71 \%$ yield

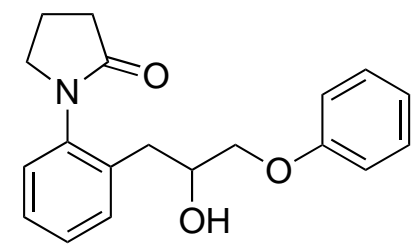

$( \pm)-78,80 \%$ yield

Scheme 10. Pd-catalyzed $\mathrm{C}-\mathrm{H}$ functionalization with $\mathrm{N}$-acyl directing groups, with regioselective epoxide alkylation.

\subsection{Mechanistic proposals}

Wang, Kuninobu, and Kanai reported the relative rates of reaction of 2-phenylpyridine (54) vs. 54- $\boldsymbol{d}_{\mathbf{5}} \mathbf{\text { with }}$ phenyl glycidyl ether (60), measuring a primary kinetic isotope effect $k_{H} / k_{D}=2.6$, indicating that the ratedetermining step was $\mathrm{C}-\mathrm{H}$ bond activation (Scheme 11). ${ }^{57}$ These scientists prepared a plausible dimeric palladacycle intermediate $\mathbf{7 9}$, but this palladacycle did not promote the ring-opening reaction with epoxide $\mathbf{6 0 .}$ They speculated that oxidation to Pd(IV) might be required for alkylation of epoxides. 
<smiles>[2H]c1c([2H])c([2H])c(-c2ccccn2)c([2H])c1[2H]</smiles>

$$
1^{\circ} \text { kinetic isotope effect }=2.6 \quad \mathbf{6 5}-\boldsymbol{d}_{\mathbf{5}}
$$

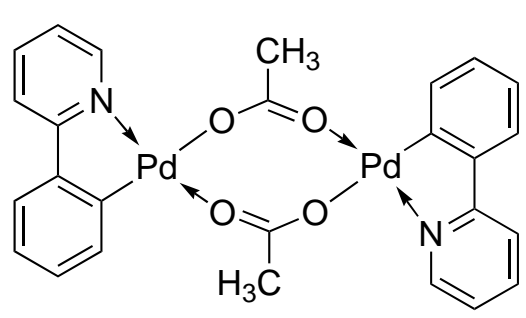

79

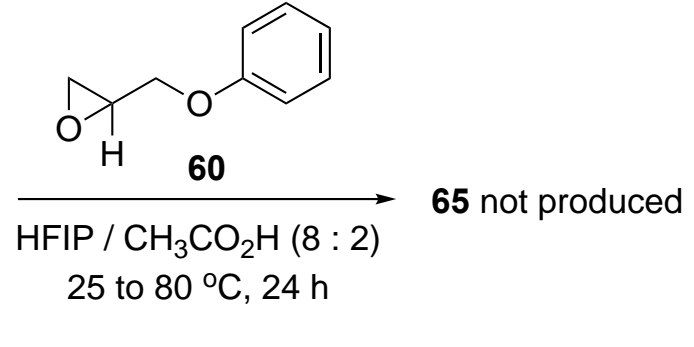

25 to $80^{\circ} \mathrm{C}, 24 \mathrm{~h}$

Scheme 11. Kinetic isotope rate study and a stoichiometric experiment with palladacycle 79 from 2phenylpyridine (54).

The Fang laboratory explored these results via density functional theory (DFT) studies. ${ }^{61}$ These scientists found that the lower energy pathway involved coordination of epoxide to a mononuclear palladacycle to form intermediate $\mathbf{8 0}$, followed by oxidative addition of the coordinated epoxide to Pd(IV) metalloxetane $\mathbf{8 1}$ (Figure 7, part a). The catalytic cycle concluded with proton transfer to form intermediate $\mathbf{8 2}$, followed by reductive elimination to yield the palladium complex with the directing group 83. In contrast, mechanisms involving only $\mathrm{Pd}(\mathrm{II})$ intermediates (Figure 7, part b) required much higher energy barriers for ring-opening coupled with carbon-carbon bond-formation. The theoretical study did not consider the effects of fluorinated solvent on the $\mathrm{C}-\mathrm{H}$ functionalization stage (not shown) to form intermediate $\mathbf{8 0}$, or on the epoxide reaction stage. 
a) via Pd(IV) intermediate 81:

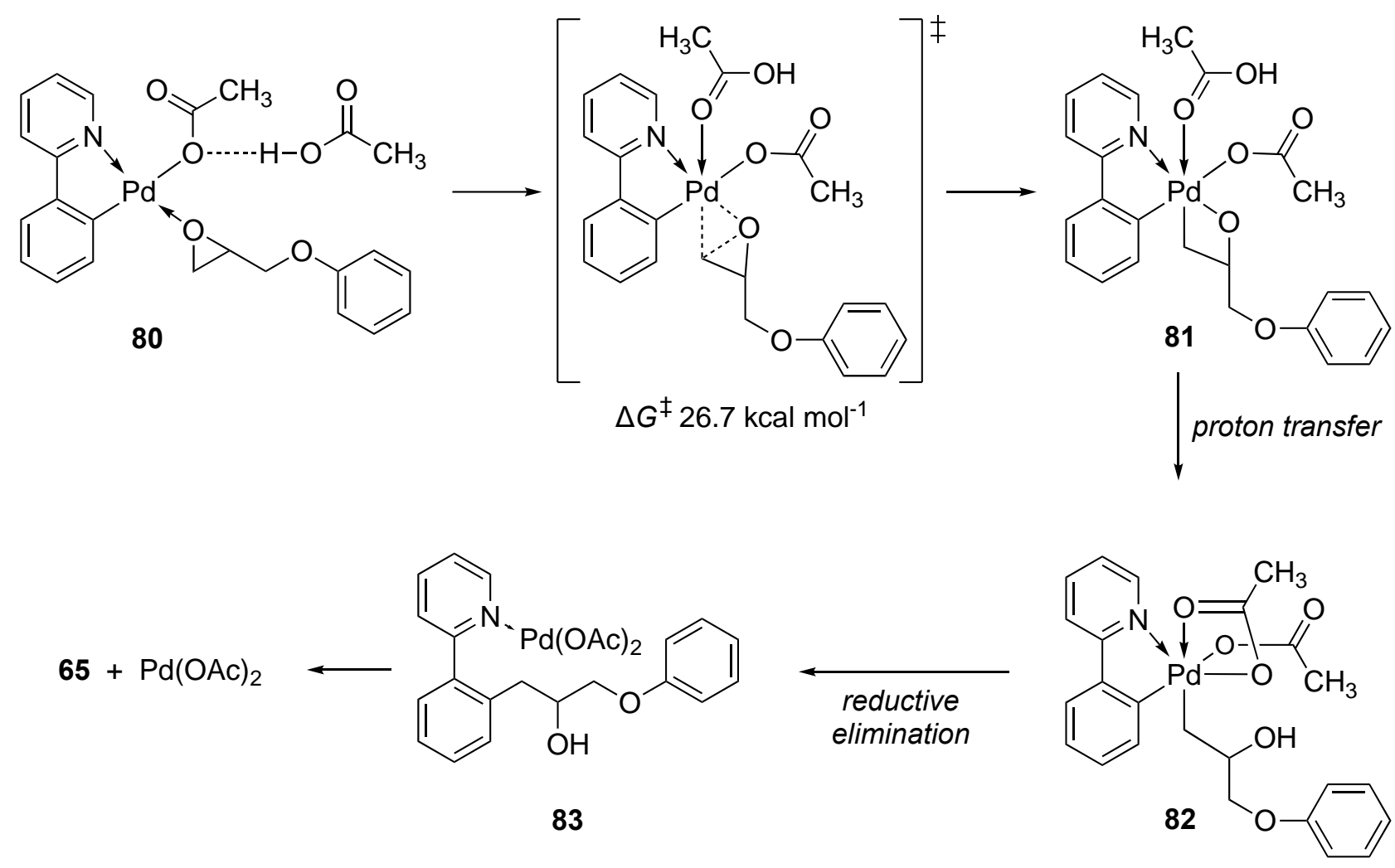

b) redox-neutral pathway via Pd(II) intermediate 80:

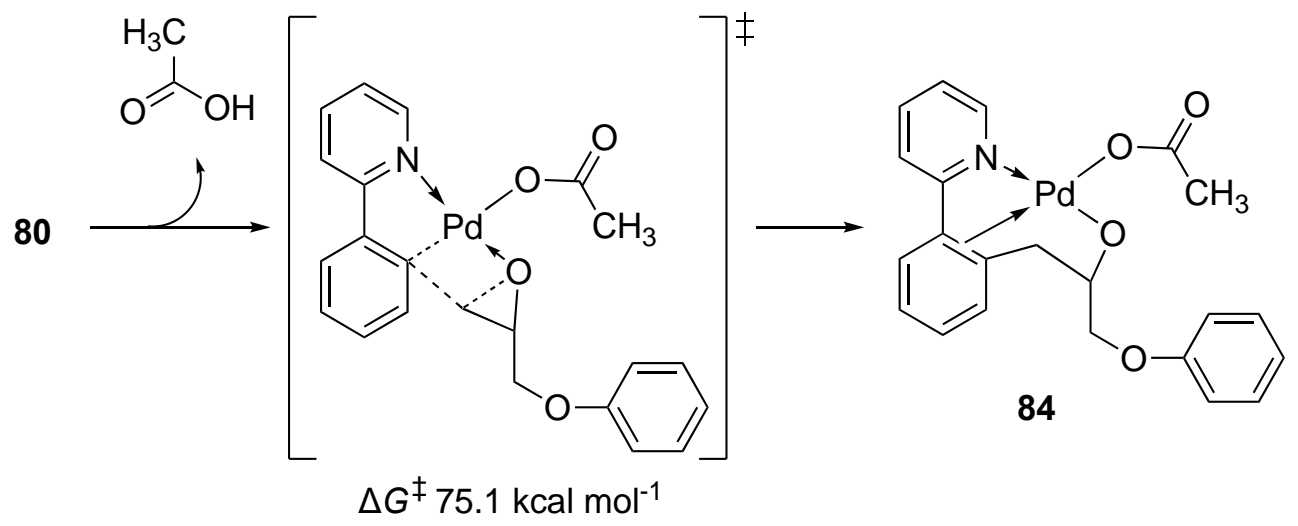

Figure 7. Partial catalytic cycles involving 2-phenylpyridine alkylation, with a Pd(IV) intermediate (path a) vs. redox-neutral pathway (path b). Determined at the B2PLYP/DGDZVP level of theory, in acetic acid $(\varepsilon=6.25)$.

In contrast, the $\mathrm{Yu}$ laboratory conducted a stoichiometric experiment with meta-toluic acid-derived palladacycle 85, which reacted with benzyl glycidyl ether (61) to produce the same compound 69 arising from catalytic conditions (Scheme 12). Moreover, the trans-stereochemistry of $\mathbf{7 2}$ arising from the reaction with cyclohexene oxide (71) suggested that the arylpalladium intermediate 85 reacted with inversion of configuration at the reactive carbon from the epoxide, without requiring a change in oxidation state from $\operatorname{Pd}(\mathrm{II}){ }^{58}$ 


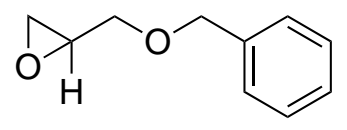

61 (1 equiv)

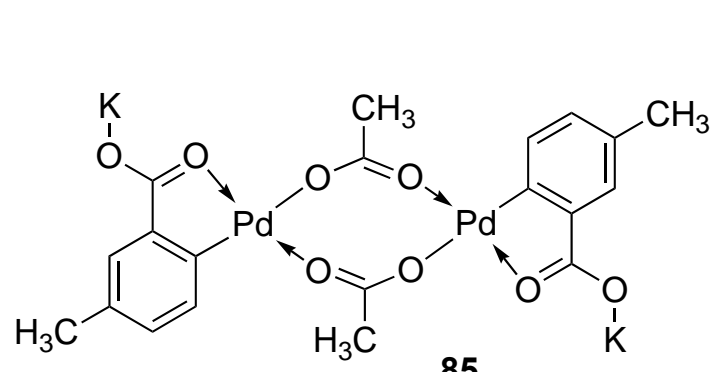

85<smiles>CC(=O)NC(CC(C)(C)C)C(=O)O</smiles>

HFIP, reflux, $24 \mathrm{~h}$<smiles>Cc1ccc2c(c1)C(=O)OC(COCc1ccccc1)C2</smiles>

$69,61 \%$ yield

proposed mechanism:<smiles></smiles>

85
86<smiles>Cc1ccc2c(c1)C(=O)O[C@@H]1CCCC[C@H]21</smiles>

$( \pm)-72$

Scheme 12. A stoichiometric experiment with palladacycle 85 from meta-toluic acid, and a mechanistic proposal based on the stereochemistry of $\mathbf{7 2}$.

In summary, we note that the carboxylic acid readily forms the anionic carboxylate under the reaction conditions. This makes the attached aryl ligand in $\mathrm{Pd}$ (II) complex $\mathbf{8 5}$ more nucleophilic for alkylation with epoxides. Neutral directing groups may uniquely require a mechanism involving Pd(IV) for epoxide alkylations.

\section{Ring-opening Reactions with Terminal Alkyne Nucleophiles}

A pair of collaborative studies from the laboratories of Sedaghat and Khalaj have described three-component coupling / cyclization methods, combining terminal alkynes, epoxides, and the active methylene compounds malononitrile (89) or dimethyl malonate (90) (Table 10). ${ }^{62,63}$ Several $\mathrm{Cu}(\mathrm{I})$ catalysts gave good to excellent yields of highly functionalized pyrans $\mathbf{9 1}$ or $\mathbf{9 2}$, corresponding to the active methylene reactant. In all cases, the best yields arose with HFIP as solvent, although satisfactory results were also reported with polyethylene glycol 400 (PEG 400, entries 5, 13). Both solvents can activate the electrophilic epoxide by hydrogen bonding with the epoxide oxygen, however, these workers did not propose a role for HFIP in alkyne activation. The non-nucleophilic nature of HFIP apparently prevented the competing addition of solvent to the epoxide, even in the presence of tertiary amine. The stereochemistry of the trisubstituted alkenes of 91 - 92 was not established in all cases, although the ${ }^{1} \mathrm{H}$ and ${ }^{13} \mathrm{C}$ NMR data suggested that isolated products may correspond to only one alkene stereoisomer. 
Table 10. Three-component reactions of phenylacetylene with propylene oxide and active methylene compounds

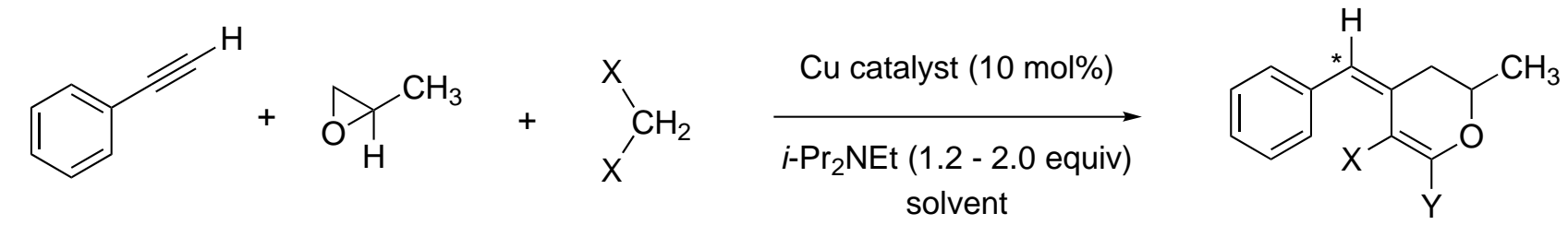
87 (1.1 - 1.2 equiv)
$( \pm)-88$
$89 \mathrm{X}=\mathrm{N} \equiv \mathrm{C}$
reflux or $85^{\circ} \mathrm{C}, 14-16 \mathrm{~h}$
$90 \mathrm{X}=\mathrm{CH}_{3} \mathrm{O}_{2} \mathrm{C}$

( \pm - $-91, X=\mathrm{N} \equiv \mathrm{C}, \mathrm{Y}=\mathrm{NH}_{2}$

(士)-92, $\mathrm{X}=\mathrm{CH}_{3} \mathrm{O}_{2} \mathrm{C}, \mathrm{Y}=\mathrm{OH}$

* alkene stereochemistry unknown

\begin{tabular}{|c|c|c|c|c|c|}
\hline entry & reactant & Cu catalyst & solvent & product & yield (\%) \\
\hline 1 & 89 & $\mathrm{Cu}_{2} \mathrm{O}$ & HFIP & 91 & 85 \\
\hline 2 & 89 & $\mathrm{Cu}_{2} \mathrm{O}$ & acetonitrile & 91 & 21 \\
\hline 3 & 89 & $\mathrm{Cu}_{2} \mathrm{O}$ & dimethylformamide & 91 & 26 \\
\hline 4 & 89 & $\mathrm{Cu}_{2} \mathrm{O}$ & PEG-200 & 91 & 40 \\
\hline 5 & 89 & $\mathrm{Cu}_{2} \mathrm{O}$ & PEG-400 & 91 & 70 \\
\hline 6 & 89 & Cul & HFIP & 91 & 80 \\
\hline 7 & 89 & $\mathrm{CuOSO}_{2} \mathrm{CF}_{3}$ & HFIP & 91 & 80 \\
\hline 8 & 89 & $(\mathrm{IPr}) \mathrm{CuCl}(92)^{\mathrm{a}}$ & HFIP & 91 & 68 \\
\hline 9 & 90 & $\mathrm{Cu}_{2} \mathrm{O}$ & HFIP & 92 & 52 \\
\hline 10 & 90 & Cul & HFIP & 92 & 61 \\
\hline 11 & 90 & $\mathrm{CuOSO}_{2} \mathrm{CF}_{3}$ & HFIP & 92 & 65 \\
\hline 12 & 90 & $(\mathrm{IPr}) \mathrm{CuCl}(93)^{\mathrm{a}}$ & HFIP & 92 & 80 \\
\hline 13 & 90 & (IPr)CuCl & PEG-400 & 92 & 51 \\
\hline
\end{tabular}

a (IPr)CuCl is [1,3-bis(2,6-diisopropylphenyl)imidazol-2-ylidene]copper(I) chloride.<smiles></smiles>

This transformation shows relatively broad scope beyond phenylacetylene (87) and propylene oxide (88):

- trimethylsilylacetylene and 1-hexyne are reactive nucleophiles;

- the opposite regioselectivity is observed for styrene oxide (7), giving dihydropyrans 94 - 95; and

- cyclohexene oxide (71) is a reactive electrophile, giving bicyclic dihydropyrans 96 - 97 (Figure 8). 

a) from styrene oxide (7)
b) from cyclohexene oxide (71)

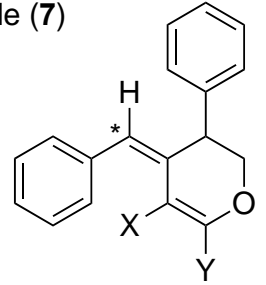
( \pm )-94, $X=\mathrm{N} \equiv \mathrm{C}, \mathrm{Y}=\mathrm{NH}_{2}(90 \%$ yield)
( \pm )-95, $\mathrm{X}=\mathrm{CH}_{3} \mathrm{O}_{2} \mathrm{C}, \mathrm{Y}=\mathrm{OH}$ (81\% yield)
* alkene and relative stereochemistry unknown<smiles>[Y]C1=C([X])/C(=C\c2ccccc2)C2=C(CCCC2)O1</smiles>
(士)-96, $\mathrm{X}=\mathrm{N} \equiv \mathrm{C}, \mathrm{Y}=\mathrm{NH}_{2}$ (95\% yield)
( \pm )-97, $\mathrm{X}=\mathrm{CH}_{3} \mathrm{O}_{2} \mathrm{C}, \mathrm{Y}=\mathrm{OH}$ (96\% yield)

Figure 8. Scope of product dihydropyrans arising from epoxide substrates $\mathbf{7}$ and $\mathbf{7 1 .}$

Experiments that generated the alkynyl alcohol intermediate 98, and related experiments that converted 4phenylbut-3-yn-1-ol (99) into dihydropyran 101 provide some mechanistic hints (Figure 9): ${ }^{63}$

a) The combination of phenylacetylene (87), propylene oxide (88), and dimethyl malonate (90) in the presence of (IPr)CuCl and refluxing HFIP, without added base, afforded a good yield of the alkynyl alcohol product 98.

- This suggests that HFIP promoted the copper-promoted formation of a copper acetylide intermediate, which has added to a hydrogen bonded-complex of epoxide with HFIP, giving 98.

b) The combination of 4-phenylbut-3-yn-1-ol (99) and dimethyl malonate 90 catalyzed by (IPr) CuCl in the absence of base and in the polar aprotic solvent $N, N$-dimethylformamide (DMF) gave the malonate addition product 100, albeit in modest yield. The catalytic loading of (IPr)CuCl was not specified in this experiment.

- The (IPr)CuCl catalyst may have deprotonated malonate (the imidazolium cation has $\mathrm{p} K_{\mathrm{a}} 21.1$ ) $^{64}$ and promoted regioselective malonate addition to the alkyne, giving 100, in a step that did not require HFIP.

c) The combination of alkynyl alcohol 99 and dimethyl malonate (90) catalyzed by (IPr)CuCl in the presence of tertiary amine and HFIP produced the dihydropyran 101 in good yield.

- HFIP alone may have promoted the final intramolecular transacylation and tautomerization; the role of the tertiary amine in this scenario was unclear.

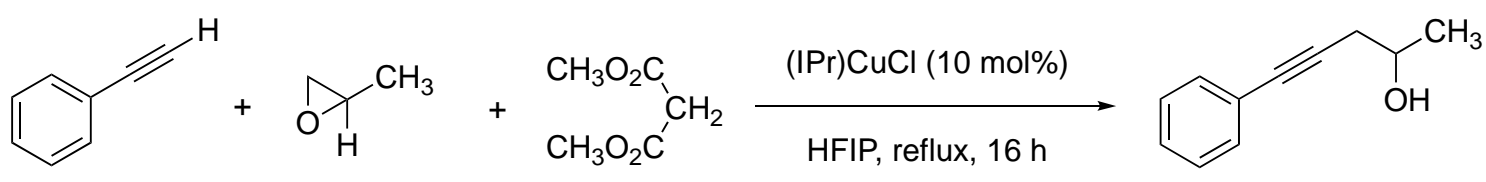

$( \pm)-88$

90

$98,67 \%$ yield

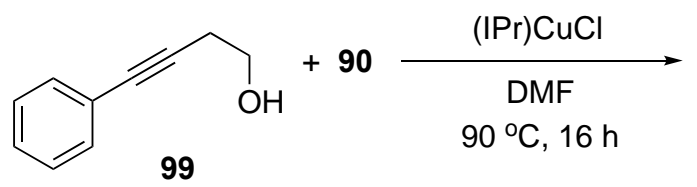

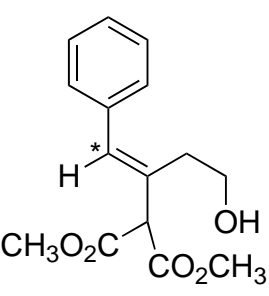

$100,37 \%$ yield

* alkene stereochemistry unknown

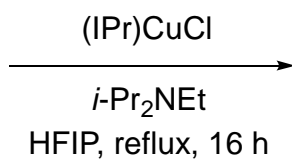

$101,72 \%$ yield

Figure 9. Individual steps via alkynyl alcohols 98 and 99. 
In summary, the combination of moderately acidic HFIP solvent with basic tertiary alkylamine without solvent addition to the epoxide is quite interesting, as similar conditions promote hexafluoroisopropoxide nucleophilic addition to phosgene and thionyl chloride electrophiles. ${ }^{65,66}$ This work merits additional investigation and optimization, particularly the direct addition of alkyne to epoxide in the absence of an active methylene compound.

\section{Ring-opening Reactions of Aziridines with Carbon Nucleophiles in Fluorinated Solvents}

This review concludes with extensions of two approaches described earlier in this review, applied to aziridine electrophiles, promoted by HFIP. In 2019, the Zhao laboratory reported palladium-catalyzed $\mathrm{C}-\mathrm{H}$ functionalization of 3-methoxybenzoic acid (102) and other arylcarboxylic acids, reacting with a relatively broad range of $\mathrm{N}$-tosylaziridines including monosubstituted 103, producing the protected beta-arylethylamine 105, an important substructure in medicinal chemistry (Scheme 13). ${ }^{67}$ The principal competing process was ring-opening of aziridine with the carboxylic acid, which was suppressed by diminishing the cesium carbonate loading to substoichiometric amounts. The conversion increased with 2,4,6-trimethylbenzoic acid (104) as a substoichiometric additive. A solvent screen revealed that a protic alcohol solvent was required, with HFIP giving the best yields.
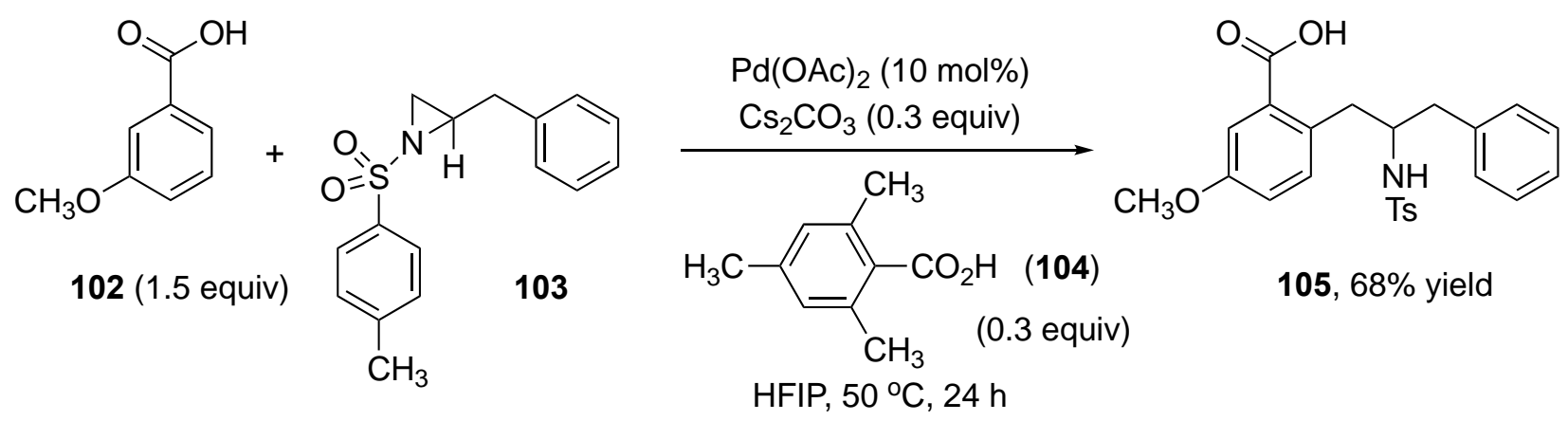

Scheme 13. Palladium-catalyzed $\mathrm{C}-\mathrm{H}$ functionalization of an arylcarboxylic acid with addition to an $N$ tosylaziridine, promoted by HFIP.

In 2019, Samzadeh-Kermani described an organocatalytic synthesis of tetrahydropyridone imines, including compound 107 (Scheme 14). ${ }^{68}$ The carbon nucleophile was an aryl or alkyl isonitrile, with cyclohexyl isonitrile (106) as a representative case. Several Lewis acids gave competing isomerization of monosubstituted aziridine 103 to a $N$-tosylimine, but tetrabutylphosphonium acetate in refluxing HFIP promoted aziridine ringopening with nucleophilic addition of the isonitrile. The base for deprotonating malononitrile (89) may have been the anionic $N$-tosylamide from ring opening, or the acetate counteranion. Nucleophilic addition of dinitrile-stabilized carbanion to the alkylnitrilium cation from the initial isonitrile addition step explains the remaining carbon-carbon bond-forming step. The author proposed that the tetrabutylphosphonium cation may coordinate with one of the nitriles to promote intramolecular nucleophilic addition of the tosylamide to close the tetrahydropyridine ring. 


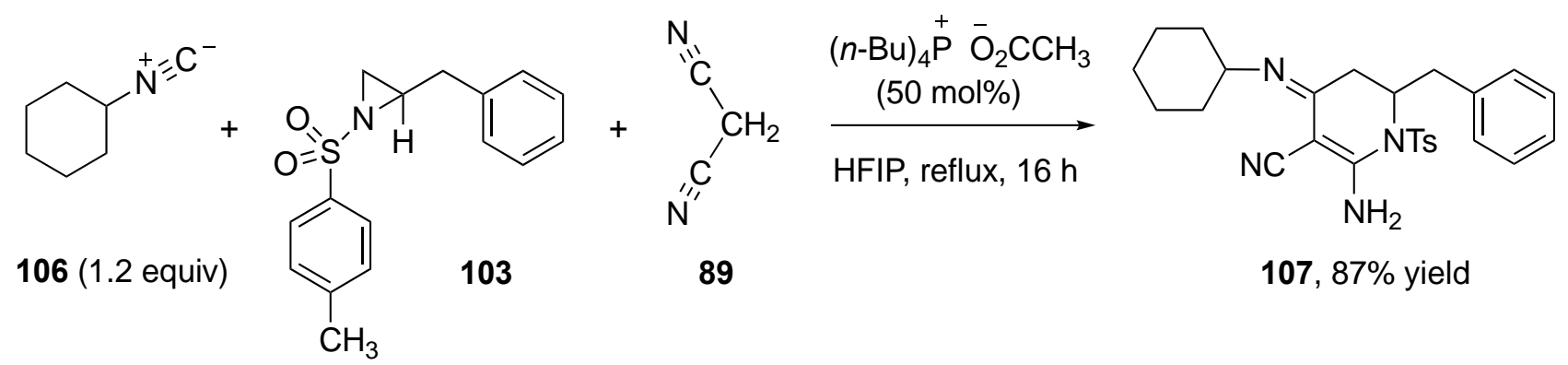

Scheme 14. Three-component coupling of an isonitrile, an $\mathrm{N}$-tosylaziridine, and malononitrile (89) to form tetrahydropyridone imines, promoted by tetrabutylphosphonium acetate in HFIP.

\section{Conclusions}

This review describes the benefits of fluorinated alcohol solvents in promoting the ring-opening reactions of epoxides and aziridines with carbon nucleophiles. The advances presented herein fall into two categories:

- significant electrophilic activation, due to the formation of complex structures and aggregations, such as the formation of an activating HFIP complex with epoxides, thereby allowing reactions with weak and neutral nucleophiles; and

- safety and environmental benefits, especially where fluorinated alcohol solvents replace Lewis acid reagents, and even more so when the solvent is recycled.

We anticipate that other researchers will find that fluorinated alcohol solvents enable other synthetically valuable transformations that have not been previously developed. The role of these solvents in activating $\mathrm{C}-\mathrm{H}$ bonds is not well-established, warranting further investigation to increase our understanding of fluorinated alcohol solvents. Additionally, there is clearly room for significant future work in aziridine ring-opening reactions in fluorinated alcohols, an area with potential for synthesizing pharmaceutical substances.

\section{Acknowledgements}

This work was supported by the Emory College of Arts and Sciences "Program to Enhance Research and Scholarship." We thank Dr. Antonio D. Brathwaite (Emory University) for initially encouraging this project. We also appreciate proofreading and comments from Tiffany Hung and Ruohan Chen (Emory University).

\section{References}

1. Reed, N. N.; Janda, K. D. J. Org. Chem. 2000, 65, 5843-5845.

https://doi.org/10.1021/j0000442t

2. Harvey, R. G. Acc. Chem. Res. 1981, 14, 218-226.

https://doi.org/10.1021/ar00067a004

3. Boone, M. A.; Tong, R.; McDonald, F. E.; Lense, S.; Cao, R.; Hardcastle, K. I. J. Am. Chem. Soc. 2010, 132, 5300-5308. 
4. Robles, O.; McDonald, F. E. Org. Lett. 2008, 10, 1811-1814. https://doi.org/10.1021/ol800659z

5. Bégué, J.-P.; Bonnet-Delpon, D.; Crousse, B. Synlett 2004, 18-29. https://doi.org/10.1055/s-2003-44973

6. Shuklov, I. A.; Dubrovina, N. V.; Börner, A. Synthesis 2007, 2925-2943. https://doi.org/10.1055/s-2007-983902

7. Wencel-Delord, J.; Colobert, F. Org. Chem. Front. 2016, 3, 394-400. https://doi.org/10.1039/c5qo00398a

8. Colomer, I.; Chamberlain, A. E. R.; Haughey, M. B.; Donohoe, T. J. Nat. Rev. Chem. 2017, 1, 0088. https://doi.org/10.1038/s41570-017-0088

9. Sinha, S. K.; Bhattacharya, T.; Maiti, D. React. Chem. Eng. 2019, 4, 244-253. https://doi.org/10.1039/c8re00225h

10. Yu, C.; Sanjosé-Orduna, J.; Patureau, F. W.; Pérez-Temprano, M. H. Chem. Soc. Rev. 2020, 49, $1643-1652$. https://doi.org/10.1039/c8cs00883c

11. An, X.-D.; Xiao, J. Chem. Rec. 2020, 20, 142-161. https://doi.org/10.1002/tcr.201900020

12. Pozhydaiev, V.; Power, M.; Gandon, V.; Moran, J.; Lebœuf, D. Chem. Commun. 2020, 56, 11548-11564. https://doi.org/10.1039/d0cc05194b

13. Richmond, E.; Yi, J.; Vuković, V. D.; Sajadi, F.; Rowley, C. N.; Moran, J. Chem. Sci. 2018, 9, 6411-6416. https://doi.org/10.1039/c8sc02126k

14. Li, F.-X.; Ren, S.-J.; Li, P.-F.; Yang, P.; Qu, J. Angew. Chem. Int. Ed. 2020, 59, 18473-18478. https://doi.org/10.1002/anie.202007980

15. Silverstein, T. P.; Heller, S. T. J. Chem. Ed. 2017, 94, 690-695.

https://doi.org/10.1021/acs.jchemed.6b00623

16. Bentley, T. W.; Roberts, I. J. Phys. Org. Chem. 2005, 18, 96-100. https://doi.org/10.1002/poc.862

17. Atik, Z. J. Chem. Eng. Data 2007, 52, 1086-1088. https://doi.org/10.1021/je700034q

18. Mejía, A.; Segura, H.; Cartes, M. J. Chem. Eng. Data 2010, 55, 428-434. https://doi.org/10.1021/je9004068

19. Laurence, C.; Legros, J.; Chantzis, A.; Planchat, A.; Jacquemin, D. J. Phys. Chem. B 2015, 119, 3174-3184. https://doi.org/10.1021/ip512372c

20. Schadt, F. L.; Bentley, T. W.; Schleyer, P. v. R. J. Am. Chem. Soc. 1976, 98, 7667-7674. https://doi.org/10.1021/ja00440a037

21. Kevill, D. N.; Anderson, S. W. J. Org. Chem. 1991, 56, 1845-1850. https://doi.org/10.1021/jo00005a034

22. Middleton, W. J.; Lindsey, R. V. J. Am. Chem. Soc. 1964, 86, 4948-4952. https://doi.org/10.1021/ja01076a041

23. Berkessel, A.; Adrio, J. A.; Hüttenhain, D.; Neudörfl, J. M. J. Am. Chem. Soc. 2006, 128, 8421-8426. https://doi.org/10.1021/ja0545463

24. Minegishi, S.; Kobayashi, S.; Mayr, H. J. Am. Chem. Soc. 2004, 126, 5174-5181. https://doi.org/10.1021/ja031828z

25. Ammer, J.; Mayr, H. J. Phys. Org. Chem. 2013, 26, 59-63. https://doi.org/10.1002/poc.3064 
26. Tavener, S. J.; Clark, J. H. J. Fluorine Chem. 2003, 123, 31-36. https://doi.org/10.1016/S0022-1139(03)00140-4

27. Brenek, S. J.; Caron, S.; Chisowa, E.; Delude, M. P.; Drexler, M. T.; Ewing, M. D.; Handfield, R. E.; Ide, N. D.; Nadkarni, D. V.; Nelson, J. D.; Olivier, M.; Perfect, H. H.; Phillips, J. E.; Teixeira, J. J.; Weekly, R. M.; Zelina, J. P. Org. Process Res. Dev. 2012, 16, 1348-1359. https://doi.org/10.1021/op300131e

28. Crank, G.; Harding, D. R. K.; Szinai, S. S. J. Med. Chem. 1970, 13, 1215-1217. https://doi.org/10.1021/jm00300a045

29. Blake, D. A.; Cascorbi, H. F.; Rozman, R. S.; Meyer, F. J. Toxicol. Appl. Pharmacol. 1969, 15, 83-91. https://doi.org/10.1016/0041-008X(69)90135-5

30. Kaminsky, L. S.; Fraser, J. M.; Seaman, M.; Dunbar, D. Biochem. Pharmacol. 1992, 44, 1829-1837. https://doi.org/10.1016/0006-2952(92)90078-W

31. Johnson, B. M.; Shu, Y.-Z.; Zhuo, X.; Meanwell, N. A. J. Med. Chem. 2020, 63, 6315-6386. https://doi.org/10.1021/acs.jmedchem.9b01877

32. Westermaier, M.; Mayr, H. Chem. Eur. J. 2008, 14, 1638-1647. https://doi.org/10.1002/chem.200701366

33. Li, G.; Bao, G.; Zhu, G.; Li, Y.; Huang, L.; Sun, W.; Hong, L.; Wang, R. Org. Biomol. Chem. 2018, 16, 36553661.

https://doi.org/10.1039/c8ob00861b

34. Li, G.-X.; Qu, J. Chem. Commun. 2010, 46, 2653-2655. https://doi.org/10.1039/B926684D

35. Hilt, G.; Bolze, P.; Harms, K. Chem. Eur. J. 2007, 13, 4312-4325. https://doi.org/10.1002/chem.200601747

36. Shuler, W. G.; Combee, L. A.; Falk, I. D.; Hilinski, M. K. Eur. J. Org. Chem. 2016, 3335-3338. https://doi.org/10.1002/ejoc.201600651

37. Llopis, N.; Baeza, A. Molecules 2020, 25, 3464. https://doi.org/10.3390/molecules25153464

38. Mayo, F. R. J. Am. Chem. Soc. 1968, 90, 1289-1295. https://doi.org/10.1021/ja01007a032

39. loganson, A. V. Spectrochim. Acta, Part A 1999, 55, 1585-1612. https://doi.org/10.1016/S1386-1425(98)00348-5

40. Lu, J.; Brown, J. S.; Liotta, C. L.; Eckert, C. A. Chem. Commun. 2001, 665-666. https://doi.org/10.1039/B100425P

41. Liu, Y.; Li, X.; Lin, G.; Xiang, Z.; Xiang, J.; Zhao, M.; Chen, J.; Yang, Z. J. Org. Chem. 2008, 73, 4625-4629. https://doi.org/10.1021/jo8005649

42. Schmid, M.; Sokol, K. R.; Wein, L. A.; Torres Venegas, S.; Meisenbichler, C.; Wurst, K.; Podewitz, M.; Magauer, T. Org. Lett. 2020, 22, 6526-6531. https://doi.org/10.1021/acs.orglett.0c02296

43. Fărcaşiu, D.; Ghenciu, A.; Marino, G.; Kastrup, R. V. J. Mol. Cat. A: Chem. 1997, 126, 141-150. https://doi.org/10.1016/S1381-1169(97)00104-0

44. Iskra, J.; Bonnet-Delpon, D.; Bégué, J.-P. J. Fluorine Chem. 2005, 126, 551-556. https://doi.org/10.1016/i.jfluchem.2004.12.008

45. Palladino, P.; Stetsenko, D. A. Org. Lett. 2012, 14, 6346-6349. https://doi.org/10.1021/ol303124r 
46. Zhao, J.-F.; Zhao, Y.-J.; Loh, T.-P. Chem. Commun. 2008, 1353-1355.

https://doi.org/10.1039/b718337b

47. Surendra, K.; Corey, E. J. J. Am. Chem. Soc. 2008, 130, 8865-8869.

https://doi.org/10.1021/ja802730a

48. Tian, Y.; Xu, X.; Zhang, L.; Qu, J. Org. Lett. 2016, 18, 268-271.

https://doi.org/10.1021/acs.orglett.5b03438

49. van Tamelen, E. E.; Willet, J.; Schwartz, M.; Nadeau, R. J. Am. Chem. Soc. 1966, 88, 5937-5938.

https://doi.org/10.1021/ja00976a048

50. Kitahara, Y.; Kato, T.; Kishi, M. Chem. Pharm. Bull. 1968, 16, 2216-2222.

https://doi.org/10.1248/cpb.16.2216

51. Kolesnikova, M. D.; Obermeyer, A. C.; Wilson, W. K.; Lynch, D. A.; Xiong, Q.; Matsuda, S. P. T. Org. Lett. 2007, 9, 2183-2186.

https://doi.org/10.1021/ol070709b

52. Tsangarakis, C.; Raptis, C.; Arkoudis, E.; Stratakis, M. Adv. Synth. Catal. 2008, 350, 1587-1600. https://doi.org/10.1002/adsc.200800180

53. Quilez del Moral, J. F.; Domingo, V.; Pérez, A.; Martínez Andrade, K. A.; Enríquez, L.; Jaraiz, M.; LópezPérez, J. L.; Barrero, A. F. J. Org. Chem. 2019, 84, 13764-13779.

https://doi.org/10.1021/acs.joc.9b01996

54. Gschwend, H. W.; Rodriguez, H. R. Org. React. 1979, 26, 1-360.

https://doi.org/10.1002/0471264180.or026.01

55. Snieckus, V. Chem. Rev. 1990, 90, 879-933.

https://doi.org/10.1021/cr00104a001

56. Nicolaou, K. C.; Gray, D.; Tae, J. Angew. Chem. Int. Ed. 2001, 40, 3675-3678. https://doi.org/10.1002/1521-3773(20011001)40:19<3675::AID-ANIE3675>3.0.CO;2-G

57. Wang, Z.; Kuninobu, Y.; Kanai, M. J. Am. Chem. Soc. 2015, 137, 6140-6143.

https://doi.org/10.1021/jacs.5b02435

58. Cheng, G.; Li, T.-J.; Yu, J.-Q. J. Am. Chem. Soc. 2015, 137, 10950-10953.

https://doi.org/10.1021/jacs.5b07507

59. Li, D.-D.; Niu, L.-F.; Ju, Z.-Y.; Xu, Z.; Wu, C. Eur. J. Org. Chem. 2016, 3090-3096.

https://doi.org/10.1002/ejoc.201600335

60. Thombal, R. S.; Feoktistova, T.; González-Montiel, G. A.; Cheong, P. H.-Y.; Lee, Y. R. Chem. Sci. 2020, 11, 7260-7265.

https://doi.org/10.1039/d0sc01462a

61. Lian, B.; Zhang, L.; Li, S.-J.; Zhang, L.-L.; Fang, D.-C. J. Org. Chem. 2018, 83, 3142-3148. https://doi.org/10.1021/acs.joc.7b03236

62. Varmazyar, A.; Sedaghat, S.; Goli-Kand, A. N.; Khalaj, M.; Arab-Salmanabadi, S. J. Heterocycl. Chem. 2019, 56, 1850-1856.

https://doi.org/10.1002/ihet.3570

63. Varmazyar, A.; Sedaghat, S.; Goli-Kand, A. N.; Khalaj, M.; Arab-Salmanabadi, S. Mol. Divers. 2020, 24, 707716.

https://doi.org/10.1007/s11030-019-09978-9

64. Higgins, E. M.; Sherwood, J. A.; Lindsay, A. G.; Armstrong, J.; Massey, R. S.; Alder, R. W.; O'Donoghue, A. C. Chem. Commun. 2011, 47, 1559-1561.

https://doi.org/10.1039/c0cc03367g 
65. Cisar, J. S.; Weber, O. D.; Clapper, J. R.; Blankman, J. L.; Henry, C. L.; Simon, G. M.; Alexander, J. P.; Jones, T. K.; Ezekowitz, R. A. B.; O'Neill, G. P.; Grice, C. A. J. Med. Chem. 2018, 61, 9062-9084. https://doi.org/10.1021/acs.jmedchem.8b00951

66. De Marco, R. A.; Kovacina, T. A.; Fox, W. B. J. Fluorine Chem. 1975, 5, 221-230. https://doi.org/10.1016/S0022-1139(00)82483-5

67. Zhou, K.; Zhu, Y.; Fan, W.; Chen, Y.; Xu, X.; Zhang, J.; Zhao, Y. ACS Catal. 2019, 9, 6738-6743. https://doi.org/10.1021/acscatal.9b01347

68. Samzadeh-Kermani, A. Monatsh. Chem. 2019, 150, 1495-1501. https://doi.org/10.1007/s00706-019-02459-7

\section{Authors' Biographies}

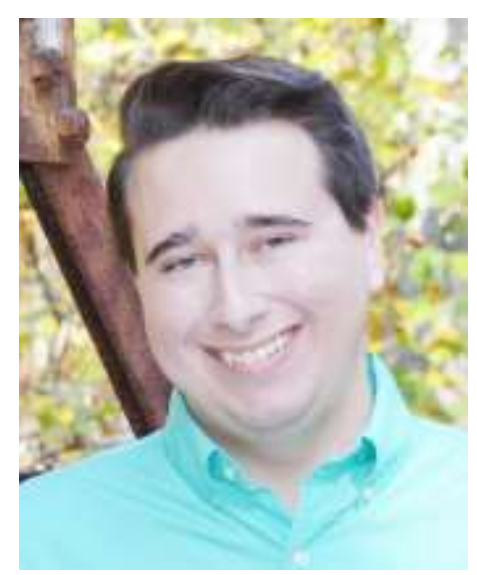

Taylor Dover joined the McDonald laboratory as an undergraduate researcher in January 2019, where he worked on developing strategies for the enantioselective synthesis of an important chiral precursor to a neuroprotectant therapeutic. While working remotely during the COVID-19 pandemic, Dover drafted this review to prepare for an experimental project on catalytic alkyne-epoxide couplings. Dover will receive his B.S. in Chemistry with a minor in Mathematics from Emory University in May 2021, after which he will pursue graduate study in Chemistry. Dover has accumulated several accolades at Emory, including the Barry M. Goldwater Scholarship (2020) and induction into the Phi Beta Kappa Society (2020).

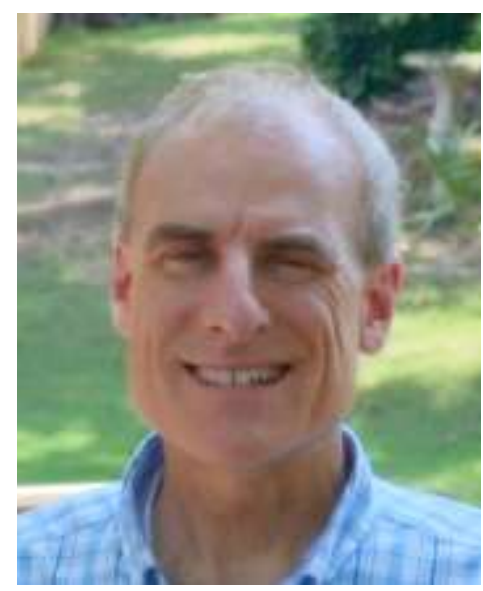


Frank McDonald completed his B.S. degree at Texas A\&M University and the Ph.D. degree at Stanford University with Prof. Paul Wender. After an American Cancer Society postdoctoral fellowship at Yale University with Prof. Samuel Danishefsky, he was assistant professor at Northwestern University, rising to the rank of associate professor, before moving to Emory University in 1998, where he is currently Professor of Chemistry. Awards and honors include the Alfred P. Sloan Research Fellowship (1995), the National Science Foundation CAREER Award (1995), Camille Dreyfus Teacher-Scholar Award (1997), Japan Society for the Promotion of Science Fellowship (2005), and the Emory Williams Distinguished Teaching Award (2008). 